\title{
MATRIMONIAL PROPERTY AND IRISH LAW: A CASE FOR COMMUNITY?
}

\author{
Lucy-Ann Buckley, Lecturer in Law, National University of Ireland, \\ Galway*
}

\section{INTRODUCTION}

Family property is a primary area of contention in property law. ${ }^{1}$ If spouses only have rights in relation to property to which they can show legal or beneficial title, they may be left unprotected in the event of marital breakdown, despite what may be a lengthy and considerable contribution to family life. If spouses have automatic rights to one another's property, injustice may result where no contribution (financial or familial) has been made. Should the law provide for property redistribution, as opposed to maintenance $?^{2}$ If a property interest is to be granted, how, and by whom, is such an interest to be quantified?

In dealing with these issues, both Ireland ${ }^{3}$ and Northern Ireland have adopted a statutory separation of assets approach, under which property rights are not automatically altered by marriage, ${ }^{4}$ and no automatic interest is conferred on one spouse in the property of the other. However, the principle of separation has been considerably eroded in recent years in both jurisdictions by the enactment of legislation conferring a judicial power of equitable redistribution of matrimonial property in the context of marriage breakdown. It is by no means certain that this represents the most appropriate or just approach to the issue of matrimonial property rights. Indeed, the Law Reform Advisory Committee for Northern Ireland has recently gone so far as to advocate the equitable co-ownership of certain matrimonial property, including in many cases the family home. ${ }^{5}$ This approach clearly derives from the principle of community property, particularly prevalent in civil law

* I would like to thank A.P Simester, Conor Hanly and Siún O'Keeffe for their comments on drafts of this manuscript. I would also like to thank Vera Orschel and Sandrine Lefèvre for their comments on the German and French sections of this paper.

1 In this article, discussion is limited to the family within marriage, and the principal rights addressed are the property rights of spouses, with some reference to maintenance. Irish law currently does not confer property rights on cohabitees (except where contributions create an equitable interest under a trusts analysis). Extensive legislative provisions apply to married couples, and the issue of extending these to unmarried partners involves policy questions outside the scope of this paper, which is primarily focused on the nature of the legislative marital regime.

2 Presuming that some level of financial support is deemed appropriate.

3 For convenience, the term "Irish" will be used to describe the law applicable in Ireland, while Northern Ireland law will be specifically identified as such.

4 An exception is the Irish Succession Act 1965 (discussed below).

5 See the section on Northern Ireland in this paper. The Law Reform Advisory Committee (LRAC) also advocated that defined property rights be extended to qualifying co-habiting persons, but this aspect of the Committee's recommendations is outside the scope of this paper. 
jurisdictions, where spouses are treated as having an interest in defined marital property due to their marital status. This interest may be vested in spouses during the marriage, or may arise only in the event of its termination on death or divorce. Advocates of community property contend that this approach is more representative of the usual marital partnership and that it promotes equality between the spouses. A key issue in Irish family law must therefore be whether a community property approach would be preferable to the current regime, or whether, indeed, a modified joint ownership approach, such as that recommended in Northern Ireland, should be adopted.

In this paper, the background to different property regimes is outlined, and the theoretical justifications for each are briefly examined. The operation of community property regimes is then analysed and compared with regimes of separation of assets and equitable redistribution. The practical operation of the current Irish approach is scrutinised, and the gradual shift towards community thinking in Irish legislative policy is analysed. Finally, it is contended that Ireland should adopt a formal and complete community-based approach, and that in this respect a system of deferred community is to be preferred.

\section{Property Regimes: The Field Of Choice}

Three principal approaches may be taken to the distribution of property between spouses: community of property, separation of assets and equitable redistribution. ${ }^{6}$ While equitable redistribution is a relatively modern phenomenon, the community and separation systems result from different historical approaches to the same difficulty, namely, how to protect the financial interests of dependent spouses, usually wives, at times and in systems where economic and political power tended to be reserved to men only.

In England, one of the principal aims of the feminist movement in the nineteenth century was to reform the marital property laws, to redress a situation where a woman's property passed to her husband on marriage. ${ }^{7}$ Ultimately, the solution adopted in England and Ireland was to give both spouses ownership and control of their own assets. ${ }^{8}$ The introduction of a separation of assets regime was therefore aimed at promoting justice for women, by protecting their property rights, independence and security. An individualist approach is taken, and neither spouse may claim property belonging to the other. ${ }^{9}$

The general feature of community regimes, on the other hand, is that some or all of the spouses' property is treated as a common fund, owned equally by

${ }^{6}$ Equitable redistribution might also be viewed as a modified form of separation of assets. It is treated here as a distinct system, as it differs from a pure separation approach in both philosophical basis and effect.

7 This was subject to limited legal protections. See Holcombe, Wives and Property (1983) for a detailed analysis of this area.

8 Married Women's Property Act 1882.

9 In common law jurisdictions, beneficial as well as legal ownership must be considered. 
each. ${ }^{10}$ Most often the fund comprises property acquired in the course of the marriage by either spouse. Marital status is crucial, as marriage automatically leads to entitlements. However, excluding cases of universal community, ${ }^{11}$ the property rights obtained generally depend on issues such as the duration of the relationship. ${ }^{12}$

The community regime was initially intended to provide a measure of security for the wife (as the dependent and legally disabled spouse), ${ }^{13}$ while also providing a mechanism for both parties to contribute to family expenses, and for the management of the family funds. ${ }^{14}$ One argument in favour of a community system is that it increases the rights of the less well-off spouse, usually the wife, ${ }^{15}$ by guaranteeing her at least some share of the family's wealth on the termination of the marriage. ${ }^{16}$ It is also perceived as a just reward for the work she has performed for the family during the marriage. In some jurisdictions, such as Sweden, a community regime was also

10 Interestingly, Bartke notes that "the concept of coequal, present ownership by the wife has been adopted grudgingly, and that originally the wife's interest was a mere expectancy". See Bartke, "Community Property Law Reform in the United States and Canada - A Comparison and Critique" (1976) 50 Tulane Law Rev 213 at 219. For a discussion of the historical background of community principles, see generally Rheinstein and Glendon, "Interspousal Relations", in International Encyclopaedia of Comparative Law, volume 4, p 47; Graue, "German law," in Kiralfy (ed), Comparative Law of Matrimonial Property (1972).

11 Such regimes arise where all assets of either spouse are comprised in the community fund, irrespective of how or when those assets were acquired.

12 E.g., under a system of acquests (where the community fund consists only of property acquired after the marriage), the longer the marriage lasts, the greater the pool of "marital" assets for division.

13 Foyer, "The reform of family law in France", p 79, in Chloros (ed), The Reform of Family Law in Europe (1978) (hereafter "Chloros (ed)"); Paulsen, "Community Property and the Early American Women's Rights Movement: the Texas Connection" (1996) 32 Idaho Law Rev 641 at 654; Graue, supra n 10, p 118.

14 Note, however, Chloros' contention that joint property systems were devised not to assert the unity of the family, but to keep the wife under her husband's tutelage; hence the preference of English law for separation of assets, as promoting the emancipation of women. See Chloros, "Principle, Reason and Policy in the Development of European Law" (1968) 17 ICLQ 849 at 858.

15 This seems evident given women's participation rates in the workforce. Ruane \& Sutherland note that overall participation by women has increased from $25.7 \%$ of the labour force in 1971, to approximately $37 \%$ by 1997 (Ruane \& Sutherland, Women in the Labour Force (1999), p 30). Of this, married women's participation rates increased from $14 \%$ to over $52 \%$ of the total female workforce over the same period. Not all of this participation represents full-time employment. In 1997, 111,000 workers out of 148,000 engaged in part-time employment were women, and $65 \%$ of women in regular part-time employment were married (p 37). Single women and married women without children have higher labour force participation than married women (as defined). Only 50\% of 25-29 year old married women with children participated in the labour market, while over $90 \%$ of married women without children and $87.6 \%$ of single women in the same age group did so (p 30). Since women's average earnings are also lower than men's (see note 22, below), it seems reasonable to conclude that the husband is the main wage earner in most families, and that wives will often lack the financial resources to acquire property on an equivalent basis.

16 Usually this would occur on death rather than divorce. 
implemented for reasons of social aspiration. ${ }^{17}$ Community regimes were seen as promoting equality between the spouses, and hence between men and women in general, by ensuring some semblance of equal rights and equal respect for the contributions of each spouse to the marriage.

The original aim of both regimes to protect dependent spouses has since been extended, and the current objective is to protect the interests of both parties. The difference is that the separation regime, in its pure form, aims to protect the rights and interests each spouse acquires in his or her own name, while the community regime aims to protect both spouses by offering both a share in property acquired by either during the marriage. This could work to a wife's detriment, ${ }^{18}$ but will more usually work to her benefit.

Pure separation of assets systems are now rare, as most are modified by a judicial discretion to redistribute property in the interests of justice on the breakdown of the marriage. Ironically, the separation regime, although introduced to protect women, was ultimately perceived as working against many of them, due to sociological factors: women's traditional work in the home means that many of them do not have the opportunity to acquire wealth, and are therefore in fact penalised by a system which decrees that they have no right to share in their husbands' property. ${ }^{19}$ The rationale of the redistributive power is to ensure that the interests of dependent family members (usually wives and children) are met, and a fair division of assets is made, while retaining flexibility to deal with varying family circumstances. No share exists unless and until awarded by the court, and spouses have merely a right to be considered for a discretionary share of property. ${ }^{20}$ Marital status alone will not guarantee a share, or a particular share: division tends to be based on contribution (financial or domestic), though increasing emphasis is placed on the idea of partnership. By contrast, in a regime of pure community, each spouse has a vested share in the marital property (however defined) from the moment of marriage. In a regime of pure separation, neither spouse has rights over the property of the other. The three approaches may therefore be viewed as points on a continuum, moving from total individualism, through individualism modified by discretionary sharing, to community or partnership.

\section{Philosophical And Theoretical Justifications For Property Regimes}

\section{i. Separation of assets}

The choice of a matrimonial property system (where separation of assets is also viewed as such) will primarily depend on the theoretical or philosophical view taken of marriage. Separation of assets may ultimately be justified by the contention that the rights of individuals should not be adulterated save by their express consent. In particular, the mere fact of

17 See Bradley, "Marriage, Family, Property and Inheritance in Swedish Law" (1990) 39 ICLQ 370 at 371-374.

18 E.g., where the wife is the principal earner in the marriage.

19 A more detailed discussion of this difficulty is contained in the following section.

20 A third possibility, deferred community, gives no vested share during the marriage, but confers one automatically on termination. 
marriage should not affect the rights of property owners, or the right to continue acquiring property for the use and benefit of the individual. In this conception, the spouses may be viewed as having agreed to share their lives in emotional or spiritual terms, or indeed in regard to daily living, but they should not be placed in an inferior position to non-married persons in terms of the acquisition of wealth. Essentially, the viewpoint is one of individualism and presumed free will: if a spouse fails to cater for personal financial security, or chooses to concentrate on other priorities, such as children, he or she cannot expect to be compensated or subsidised by the other spouse. If need is an issue, this is something to be dealt with in other ways, for example, with the assistance of the state.

In this context, individualism is lauded both for philosophical reasons and for its perceived social benefits. Philosophically, the rights and free will of the person are viewed as paramount, and as essential for personal selfdevelopment. Individuals are therefore to be preferred to artificial social groupings, which may or may not last. Although marital sharing is desirable, the sharing in question is one of experiences, rather than wealth, and is argued to be at its best when both parties are equal and independent. ${ }^{21}$ Socially, it is argued that individualism particularly promotes financial independence and responsibility, which is ultimately preferable to a prolonged financial dependency for either spouse or former spouse. Individualism also promotes equality of the sexes, as women are encouraged to seek financial independence, for example, by means of a career.

Although the promotion and protection of individualism may be accepted as a valid social and philosophical goal, it is clear that there is a price to be paid. While the pure individualist doctrine assumes that both parties to a marriage are equally able to accumulate wealth, social reality clearly demonstrates that this is not so. In practice, except in childless marriages where childcare is not an issue, one of the parties will almost invariably have to subsume his or her career to family needs. This is not always a matter of choice, though sometimes it may be; it may well be that alternative means of childcare are unavailable. For social and financial reasons (for example, because women statistically tend to earn less than men, ${ }^{22}$ or because of socialised gender roles), it will usually be the woman whose career is thus subsumed, and who is therefore impeded in her acquisition of wealth. Even should she later return to the market, she is unlikely to do as well as she otherwise might have done, as she will be hampered by age, lack of seniority, unfamiliarity with new techniques and the obsolescence of old ones.

21 See, e.g., Powell, "Community Property - A Critique of its Regulation of Intrafamilial Relations" (1936) 11 Washington LR 12.

22 Ruane and Sutherland note that the average weekly industrial earnings of females in Ireland in 1997 were only $64.37 \%$ of men's. The average hourly earnings for women comprised $72.93 \%$ of the average for men when all industries examined were considered, and in fact the ratio was considerably lower in some sectors (supra n 15, p 58). Within the corporate sector, female managing directors earned only $75 \%$ of the salary of male equivalents, and females in other management ranks earned around $86 \%$ of the salary for male equivalents (ibid $\mathrm{p} 69$ ). 
To treat the woman's subsequent financial vulnerability solely as the result of her individual choice is to ignore the fact that such a choice will usually be a matter of implicit or explicit agreement between the spouses. In other words, the spouses have both agreed on a division of labour, and it is the choice of each that one should earn for the family while the other works in the home. It is surely unlikely that a home-making spouse would agree to forego the chance of personal gain unless she believed that she would share in the financial gains made by her partner, and thus have an equal chance of financial security; it is also surely unreasonable that the earning spouse would expect the homemaker to do so. If this is the proper 'default' understanding of the marital bargain, ${ }^{23}$ it is unjust for one spouse only to be faced with bearing the cost of the decision. A pure separation approach to property effectively allocates the negative consequences of the spouses' bargain to one spouse only, and ignores the other spouse's complicity in the arrangement.

Despite arguments that a separation of assets regime ultimately compels women to take responsibility for acquiring wealth on their own behalf, there is no clear evidence that this is the case in the Irish context. Although separation of property has been the dominant approach in Ireland and the UK since the passing of the Married Women's Property Act 1882, it is only in recent decades that women have remained in employment after marriage, in significant numbers. ${ }^{24}$ This would suggest that, in itself, a separation of assets regime is unlikely to encourage labour market participation by married women. As against this, married women's lower employment rates may not always have resulted from individual choice. Until Ireland joined the European Economic Community, and was compelled to introduce gender equality legislation, many women, particularly those employed in the public sector or in banking, were compelled to leave their employment on marriage. ${ }^{25}$ The constitutional emphasis on women's work in the home ${ }^{26}$ may also have contributed to this trend. Married women might therefore find themselves effectively debarred from earning on their own behalf, even if they wished to do so. It is therefore impossible to say with certainty whether the rise in employment participation by married women is linked to a separation regime or to changing attitudes to gender equality and the financial needs of the family as a whole.

\section{ii. Sharing of assets - equitable redistribution and community of property}

Two reasons advanced for property redistribution (of any kind) are status and contribution. Under a status argument, spouses are automatically entitled to share in each other's wealth simply because they are spouses; the fact that they have chosen to marry, rather than simply cohabit, is viewed as implying that they intend to tie their lives together in every sense. Under a contributory approach, a spouse is entitled to share in the other spouse's property because she contributed to its acquisition, by directly helping to purchase it, or by indirectly enabling the other spouse to acquire it, for

23 Clearly, this understanding may be varied by agreement.

24 See note 15 , above.

25 The so-called "marriage bar".

26 Art 41.2.2 of the Irish Constitution. 
example, by relieving him of other charges. The contributory approach has long been adopted by the courts of Equity, in the form of the purchase money resulting trust, ${ }^{27}$ as it is assumed that a person would not contribute to the acquisition of an asset without receiving a share in it.

Both the status and contribution arguments may be subject to criticism: why should the mere fact of marriage entitle one spouse to a share of the other's (perhaps hard-earned) wealth, in particular where the marriage is of short duration? If contribution is the key requirement, how is that contribution to be quantified? Is it limited to financial contribution (which many women may not be able to make), or can domestic labour, childcare and psychological and emotional support be taken into account? A particular criticism of a contributory approach has long been that the emphasis on direct financial assistance ignores the value of work in the home and childcare, which the earning party would otherwise have to pay for or undertake personally. Although contributions for trusts purposes have been expanded in many jurisdictions to include the payment of household bills, domestic labour and childcare are still not generally accepted as contributions giving rise to beneficial entitlements. ${ }^{28}$ However, legislation frequently now includes work in the home as a contribution for the purposes of equitable redistribution. ${ }^{29}$ In this context, contributions include contributions to the overall well-being of the family, not merely to the acquisition of property.

Paradoxically, just as a separation of assets approach is said to rest on equality, so also is a community of property regime. ${ }^{30}$ In the separation approach, equality is said to arise because each of the spouses has an equal opportunity to acquire and retain wealth for personal benefit, although (as previously discussed), this vaunted equality of opportunity may be more apparent than real. Community of property, on the other hand, is said to rest on the concept of equality because the contribution of each spouse to the marriage is valued equally. The husband and wife are akin to business partners, engaged on a joint enterprise. Each contributes equally to the success of the marriage, in his or her different way. The purpose of the partnership is to create a successful marriage, and this can only be achieved where each contributes fully, either financially or otherwise. As each contribution is equally essential, neither contribution can or should be valued more than the other. Each spouse has an equal stake in the marital venture, and each is therefore entitled to an equal share in the marital profits. To say otherwise unjustly devalues the contribution of one spouse and reinforces an assumption that only contributions in money or money's worth (as rigidly determined by the courts) are significant.

27 The resulting trust is not limited to marriage, and indeed may be less available to spouses in some situations (e.g., where the presumption of advancement is held to apply).

28 See note 113 for greater detail.

29 See the sections on New Zealand and Ireland in this paper.

30 Under current Irish legislation, equality is not a consideration when the court is exercising its powers of equitable redistribution. See also the comments of McGuinness $\mathrm{J}$ in the recent case, $M K \mathrm{v} J P$ (otherwise SK) (Supreme Court, unreported, 6 November 2001), discussed below. 
Equality, status and contribution may now be subsumed into the broader heading of partnership and sharing. It has been argued that the true explanation and justification for the sharing of marital property is the presence of "common expectations" or "sharing principles". ${ }^{31}$ In other words, neither marriage nor contribution alone will entitle a spouse to a share in property, but a share may be granted where the parties intended to own things in common, and to act as if the marriage were a partnership. ${ }^{32}$ Here the criticism of the individualist approach is not based on, or solely on, the practical consequences of a separation approach. Instead, it is contended that individualism is an inappropriate guiding precept in relation to marriage or family property issues. There is a fundamental division between those advocating individualism, and those arguing in favour of communality or sharing. To the latter, it is simply not true to say that a marriage consists of individuals only, and that the same rules should therefore apply as would apply to complete strangers. As Gardner expresses it,

". . . the values which society expects to characterise the dealings between parties to an emotional partnership are not those of individual autonomy and discrete responsibility, but those of trust and collaboration". 33

The approach here is not one of calculating relative profits or losses, which might require compensation or reallocation, but of recognising that the parties to a marriage will usually think in terms of joint rather than individual needs and gains. Although there may be situations where there was no such intention, it would seem reasonable to argue that it is a more appropriate "default understanding" of marriage than pure individualism, and that communality should generally be assumed in the absence of evidence to the contrary. ${ }^{34}$

To the "sharing" argument may be added one of human dignity. Unlike those who argue that separate property ownership fosters equality and responsibility, and hence (presumably) dignity, communitarians argue that it is the failure to reward both contributors to the marriage that undermines dignity. Women's dignity, in particular, is undermined by the legal view that non-earning parties, usually wives, contribute less to the marriage. As Vaughn notes,

"The law in the common law states fails to recognize the wife as a helpmate and partner engaged with the husband in the

31 See, e.g., Prager, "Sharing principles and the future of marital property law" (1977) 25 UCLA Law Rev 1. However, see also Glendon's comments in Glendon, The New Family and the New Property (1981), chapter 2.

32 Common expectations should not be restricted to situations where the parties have specifically addressed the issue of property ownership: as Gardner and others have noted, this may rarely happen. Thus, Gardner argues that the better view is to look for the broader concept of "trust and collaboration." See Gardner, "Rethinking Family Property" (1993) 109 LQR 263.

33 Ibid at 286.

34 E.g., by the existence of a pre-nuptial agreement stipulating otherwise. 
common enterprise of creating a family as well as a fortune, and refuses her the place of dignity to which she is entitled." 35

If communality or sharing is accepted as the usual basis for marriage, it follows that the law should incorporate sharing principles by adopting some form of property sharing rather than a separation-based approach. Clearly, what is then required is a policy decision as much as one of principle, in terms of how this understanding should be implemented. Should the sharing be pre-determined and automatic, or should it vary with individual circumstances?

This question is linked with the final concern in this area, namely, justice. Like equality, this is paradoxically a concern of both sharing and separation approaches. In the separation of assets model, justice requires that a person's (often hard-earned) property remains exclusively his. ${ }^{36}$ In a community or redistribution approach, justice requires that the contribution of the other spouse towards the acquisition should be recognised, and that the couple share the property acquired. A community regime assumes that justice should almost always result in an equal sharing; under equitable redistribution, justice and sharing may be informed by other considerations, such as need, earning potential and responsibilities. Consequently, equality is not always justice.

As between equitable redistribution and community of property, each system has advantages and disadvantages. Equitable redistribution offers a flexibility that a community approach cannot match, and the factors taken into account are generally fair and pertinent. For example, it seems reasonable to argue that a spouse of many years' standing should obtain a higher share than one newly married. The longer the parties have lived together, the more likely and appropriate it may appear for them to intend to share things and own them jointly. It also seems fair that a person who has contributed, in whatever manner, to the acquisition of wealth should participate in its benefits. Sharing and contribution principles may overlap here: if both spouses contributed to an asset, it seems likely that they intended to share it. If a broad approach is taken, emotional support and psychological commitment might also be taken into account in assessing contribution to the overall relationship, ${ }^{37}$ though it is not clear what conduct

35 Vaughn, "The Policy of Community Property and Inter-spousal Transactions" 19 Baylor LR 20, cited in Reppy and Samuel (eds.), Community Property in the United States (2nd ed, 1982), p 4.

36 One of the arguments most frequently advanced against automatic sharing is that it may lead to injustice, as the owner of property may be deprived of it after a short marriage by someone who has not contributed to the acquisition of the property (see generally Oldham, "Is the Concept of Marital Property Outdated?" (1983/84) $22 J F L 263$ ). In fact, the share of property reallocated in either system discussed above will generally depend on factors such as the duration of the marriage; this may be an explicit factor for the deciding court to consider (as in the Irish legislation, discussed below), or may automatically serve to limit the property available for distribution, as in the French or German systems (discussed below).

37 E.g, in Black v Black [1991] DFC 95 (Lexis citation), the New South Wales Court of Appeal noted that the "activities of a homemaker involve not only physical activities about the house but also the provision of support, love and affection. . . necessary to maintain a happy family unit". 
should suffice in this regard. Other factors, such as the existence of children, or the fact that one person forewent opportunities for the overall good of the family (for example, by missing job opportunities), also merit consideration. ${ }^{38}$

By contrast, a community regime presumes from the beginning that the couple intended to share everything equally, in the absence of evidence to the contrary. ${ }^{39}$ Both spouses are therefore aware from the start of their property entitlements, and that their individual efforts will advance the interests of both. ${ }^{40}$ The community regime is therefore not only based on sharing, but also promotes it, as it strengthens the emotional and economic marital partnership.

\section{Classification of Community Property Regimes}

In order to provide a greater understanding of how community regimes operate, two contrasting models (those currently in use in France and Germany) will now be examined briefly. ${ }^{41}$ These will then be contrasted with the system of separation of assets, which, ameliorated by equitable redistribution, is currently in force in Ireland. The applicable law in New Zealand, which incorporates elements of both systems, will also be briefly discussed, as will the recent proposals of the Law Reform Advisory Committee in Northern Ireland.

\section{Community Property In French Law}

When two people marry in France, they necessarily opt for a particular financial arrangement, ${ }^{42}$ either voluntarily or involuntarily. They may consciously select a particular marital regime, or devise one to suit their particular needs $;{ }^{43}$ if no choice is made, ${ }^{44}$ the law provides that the "legal

38 Indeed, it has been suggested that unless such factors as these are present, no real redistribution of assets should take place (see Oldham, supra $\mathrm{n} 36$, at 287). This is justified variously on the basis of non-contribution, lack of true commitment, and equality (a refusal to "patronise" women, or a fear that injustice will be done to men); ibid at 284-286. Again, however, these factors can be combined with a sharing analysis: children (apart from requiring maintenance in themselves) may well demonstrate partnership and commitment to a relationship, as may a distribution of labour in the perceived best interests of the family. (This is certainly not to say that no such partnership can exist without children).

39 Such as the couple contracting out of the statutory regime.

40 Expectation, in this context, may also justify sharing.

41 The French and German systems remain two of the most influential community property regimes, with equivalents being adopted in many other jurisdictions, and offer an interesting insight into some of the different ways in which community property may operate.

42 Unmarried couples, including same-sex partners, have recently been permitted to organise their community life and define their property rights and responsibilities through a "civil pact of solidarity" (PACS) under the law of 15 November 1999.

43 Since 1965, the Civil Code offers the separation of goods or participation in acquests (effectively a form of deferred community) as alternatives to the legal regime. The spouses may also devise their own marital regime, but cannot depart from the basic requirements (or "primary regime") contained in Title V, Chapter I of the Civil Code. 
regime" will apply, and the spouses are deemed to have selected the system laid down in Article 1400 et seq. of the Civil Code.

The legal regime has been radically altered on a number of occasions, in response to social and historical changes..$^{45}$ The current system was introduced in $1965^{46}$ and is confined to acquests only. The community is subject to the debts and liabilities of the marriage. The assets include all goods gainfully acquired by the spouses either separately or together, in the course of their marriage. ${ }^{47}$ They also include the fruits or income derived from the goods they own separately. ${ }^{48}$ Each spouse has the right to manage the jointly-held property. ${ }^{49}$ However, the spouse making a decision will be responsible to the other spouse for any errors. ${ }^{50}$ Where either spouse has a separate profession, he or she has the sole power of management in that regard. ${ }^{51}$

There are three funds into which all property must fall, namely, the husband's fund (his separate property), the wife's fund (her separate property), and the community fund (joint property). Each spouse is entitled to half the property acquired during the marriage, regardless of financial contribution. To determine which property belongs to which fund, it is necessary to have regard to particular principles. For example, classification of property according to its origin ${ }^{52}$ or its nature ${ }^{53}$ may result in its allocation to a particular fund. The liabilities of the community consist of the debts incurred by each spouse, in the course of the marriage. The creditor may satisfy these debts from the jointly-held property, unless the spouse who owes the debt committed fraud, and the creditor was not acting in good faith. However, even if a debt is binding on the community, compensation may be

44 Until recently, it appears that few couples exercised the right to opt out of the default system. However, Bell et al note that $60 \%$ of French spouses now choose to be subject to a separation of assets regime: Bell, Boyron and Whittaker, Principles of French Law (1998), p 225.

45 Factors influencing change include the trend towards contracting out of the previous legal regime (of movables and acquests) and the perceived injustice of that regime. A third cause of change has undoubtedly been the rise of gender equality concerns. See International Encyclopedia of Comparative Law, paras 4108 to 4-110. For an account of the pre-1965 regime(s), see Amos, Amos \& Walton's Introduction to French Law (1967), chapter 12.

46 Under the law of 13 July 1965.

47 Art 1401 C Civ.

48 Ibid.

49 Art $1421 \mathrm{C}$ Civ. Originally, the husband had sole powers of management, but this was changed by the law of 23 December 1985.

50 Art 1421 C Civ.

51 Ibid.

52 Art $1401 \mathrm{C} \mathrm{Civ}$ provides that the community consists of acquisitions made by the spouses together or separately during the marriage, as a result of their personal skill, as well as savings made from the fruits and revenues of their own property. Under art $1405 \mathrm{C}$ Civ, property acquired before marriage belongs to the spouses' individual funds, as does any property acquired by gift or inheritance during the marriage, unless otherwise specified. Joint gifts to spouses are presumed to belong to the community.

53 E.g., personal items (such as clothing or compensation actions for injuries) are separate property belonging to the individual, as are things essential to a separate profession (art 1404 C Civ). See also arts 1405-1408 C Civ. 
payable in some cases. ${ }^{54}$ The separate property of a spouse is not available to creditors of the other spouse, unless the debt is for household expenses or the children's education. ${ }^{55}$

The aim of the legal regime is to give each spouse independence with respect to his or her earnings and separate property, but to provide a form of joint management of common property where important transactions are concerned. Each spouse has complete control over his or her separate property. ${ }^{56}$ However, if the regime is liquidated, each spouse may be held responsible to the community if he or she failed to collect the fruits of his or her separate property, or consumed them fraudulently, during the previous five years. ${ }^{57}$ In addition, while the spouses have joint and several powers of administration over the community, certain important acts can only be done jointly. ${ }^{58}$ Consent is required for gifts, the sale or mortgage of immovables or commercial enterprises, and for the alienation of any asset subject to the requirements of registration. ${ }^{59}$ A second consent is required before the contracting spouse can collect the purchase price. Finally, the matrimonial home and contents receive special protection under French law. ${ }^{60}$

The community fund is protected by various devices. ${ }^{61}$ If either spouse defaults seriously in his or her duties, so as to jeopardise the family's interest, the family court judge may order urgent protective measures, and forbid the defaulting spouse to dispose of his or her own or community property without the consent of the other spouse. ${ }^{62}$ Where a divorce suit is pending, a judge may order any steps necessary to protect the rights of a spouse and the common property. ${ }^{63}$ Ultimately, a spouse may sue to put an end to the community, if this is necessitated by the misconduct of the other spouse. ${ }^{64}$

The community property regime will automatically terminate on death, judicial separation or divorce. ${ }^{65}$ The couple's acquests will then be itemised and divided equally between them (or, in the case of death, between the

54 E.g., where a community has paid the personal debt of a spouse, compensation is payable by that spouse to the community. See arts 1409-1418 C Civ for the debts of the community.

55 Art 1414(1) C Civ. This might be relevant where neither the spouse who incurred the debt nor the community has sufficient to discharge the debt.

56 Art 1428 C Civ.

57 Art 1403 C Civ.

58 For example, both spouses are required for a gratuitous disposition of community property; see Art 1422 C Civ.

59 Arts 1424 and 1425 C Civ.

60 Art 215 C Civ states that neither spouse can dispose of the rights which secure the family home or furniture without the consent of the other. The transaction may be authorised by the Court if consent is unreasonably withheld only where the act is being done in the interests of the family. Where one spouse has not consented to the disposition of the family home, he or she may apply to the Court to avoid the transaction within one year of becoming aware of it.

61 Originally, the aim of these devices was to protect the wife's interest, given the potential for abuse by the husband: see Foyer, in Chloros (ed), supra n 13, p 86.

62 Art 220(1) C Civ.

63 Art 257 C Civ.

64 Art 1443 C Civ.

65 Among other grounds; see Art 1441 C Civ. 
surviving spouse and the estate of the deceased spouse). Maintenance may also be payable in the context of divorce or separation. ${ }^{66}$ In the case of death, the surviving spouse may also be entitled to a share of the deceased's separate property. ${ }^{67}$

\section{Deferred Community In German Law}

Like the French, the Germans opted to create a default statutory regime, which would apply unless the parties specifically opted for an alternative. ${ }^{68}$ However, the statutory regime originally adopted was not one of community, but one of separation of assets, wherein the husband was given powers of administration over his wife's property. The wife retained legal title to the property she brought to the marriage, both real and personal, but lost the rights of administration, possession and profits to her husband. Alternative systems were also available, and the parties retained the power to alter the regime after marriage. ${ }^{69}$ However, such changes would not be effective against third parties unless they were registered in the matrimonial property register operated by the county court.

As in France, social conditions changed greatly after the introduction of the original system. After World War II a "community of increase"70 was adopted as the default regime. This is often described as a hybrid system, as it presents characteristics of both the separate property system and the community system. The aim is to divide the increase in value of the property equally between the spouses, at the end of the marriage. The spouses retain their separate property so long as the marriage continues, but if they divorce, the spouse with the larger increase must give half the difference in value to the other. ${ }^{71}$ This is essentially a system of deferred community. If the marriage ends on death, an extra quarter of the deceased's estate is generally added to the surviving spouse's statutory portion, irrespective of any increase in the value of either spouse's property during the marriage. ${ }^{72}$

The German system does not provide for the sharing of all marital property, but merely for the sharing of the increase in value of marital property. All that is given is a money claim, rather than the right to any particular asset. During the marriage, there is no marital fund (as there is in the French system), but only the separate funds of either spouse. ${ }^{73}$ No distinction is

66 Arts 282 and 293 C Civ.

67 Art 767 C Civ.

68 Alternatives to the statutory regime include the separation of assets and a community of property (effectively universal community, subject to exceptions and reservations).

69 This was not possible in France prior to the 1965 reforms.

70 Zugewinngemeinschaft. For a detailed account of the general background and the current system, see Thiele, "The German Marital Property System: Conflict of Laws in a Dual-nationality Marriage" (1982) 12 California Western Intl LJ 78, or Graue, supra $\mathrm{n} 10$.

$71 \mathrm{~S} 1378(1)$ BGB. However, even though property ownership is separate, and the property is administered independently, the spouses are limited in the exercise of their powers in some respects: see sections 1364-1366 and 1369 BGB.

72 S 1371 BGB.

73 Thiele considers that the term "deferred community" is a misnomer, when applied to German law, "because no genuine community is created. Rather, the new 
made with regard to how the increase was arrived at. ${ }^{74}$ The division is confined to increases in value: there is no concept of sharing a loss suffered by the other spouse, as there is in French law.

In terms of valuing the initial estate of each spouse, the spouses may agree an inventory of initial belongings, which is then presumed to be correct. ${ }^{75}$ If no inventory is agreed, there is a presumption that there was no initial estate, with the result that each spouse will be assessed on the full value of their current property, i.e. everything the spouse now owns is treated as an "increase". Consequently, the difference in total value of the two estates is divided between the spouses. Since few couples will trouble to prepare an inventory, what was intended to be a division of the difference in increase in value often ends up as a division of the difference in total value of the spouses' estates. However, a saving provision provides that if there is a "grave inequity," the court is given a certain measure of discretion in assessment and division. ${ }^{76}$ Finally, even though neither spouse has an interest in the specific assets of the other, each needs the other's consent for certain transactions.

Overall, the German marital regime provides for each spouse in the event of death or divorce, while leaving a high degree of independence to each during the course of the marriage. It achieves this aim in quite a different manner to the French community system, as in Germany no community or claim exists until the property is being divided. The division of the increase is designed to leave the two parties benefiting equally from the marriage, however they contributed during the course of the relationship. This may lead to some unfairness, but by and large, the premise is the same as in the French system: it is presumed that the parties are true partners, and entitled to equal distribution, save in cases of extreme inequity.

\section{Community Property In New Zealand}

The law on division of matrimonial assets in New Zealand represents an interesting compromise between the certainty and sharing aspects of the community property approach, and the flexibility and concern for needs and justice of equitable redistribution. Under the Matrimonial Property Act 1976, the contributions of both spouses to the marriage partnership are

regime is one of separate property during marriage, with compensation or balancing of the individually-won gains upon termination of the marriage" (supra n 70, at 84). Similarly, Graue comments that the spouse's share of the other's gain constitutes a "compensatory debt," and that there is no community as such, since there is no split in title. See Graue, supra n 10, at 126.

74 The only exception relates to gifts and inheritances during the marriage: these are added to the "initial value" of the relevant spouse's property, i.e. she is treated as if the property was acquired before marriage, and thus will not have to divide the value of the increase it represents.

75 Unless the parties listed their assets in an inventory prior to the marriage, all assets are presumed to have been acquired after the marriage (s 1377 BGB). This approach is not free from criticism, see e.g. Neumayer, "General Introduction: Report on Comparative Law", in Chloros (ed), supra n 13, p 14.

$76 \mathrm{~S} 1381$ BGB. S 1381(2) provides that gross inequity can exist particularly if the spouse who made a smaller increase over a considerable period negligently failed to carry out the economic obligations which are inherent in marital relations. 
recognised as equal, and the concern of the Act is to provide for a just distribution of assets when the marriage ends by separation or divorce. Property is divided into matrimonial and separate assets, with only the former being subject to the Act. As in Germany, there is no community during marriage, and property division is deferred until termination of the relationship. It is also possible to avoid the application of the legislation by formal agreement, subject to review by the courts. ${ }^{77}$ Matrimonial property is defined as all property acquired by either spouse after the marriage, together with assets acquired after marriage for the couple's common use and benefit out of property they owned before marrying, and any pension or other entitlements arising after marriage. ${ }^{78}$ Separate property is defined as property acquired by either spouse while they were not living together, unless the court considers it just in the circumstances that such property should be treated as matrimonial property. ${ }^{79}$ Hence, matrimonial property is generally limited to assets acquired before the parties ceased to live together, or at the latest, by the time of the proceedings. The former date determines the right to a share, and the latter determines the valuation.

In principle, the matrimonial property is divided equally between the husband and wife, and the Act proceeds on the premise that the efforts of one spouse in the domestic sphere are intended to free the other spouse to concentrate on working outside the family home, to the benefit of the family as a whole. Hence, each spouse is taken as contributing in a different but equally important manner to the marriage partnership. ${ }^{80}$ The 1976 Act subdivides matrimonial property into two categories. The first category, consisting of the matrimonial home and chattels, is shared equally between the spouses $^{81}$ unless the marriage is of short duration ${ }^{82}$ or there are "extraordinary circumstances" making such equal sharing "repugnant to justice". ${ }^{83}$ In this situation, the assets are shared in accordance with the contribution of each spouse to the marriage partnership. ${ }^{84}$ The second category comprises all other matrimonial property; here, there is a presumption of equal sharing, unless the contribution of one spouse to the marriage partnership has been clearly greater than that of the other, in which case the property is shared in accordance with the contribution of each to the marriage partnership. ${ }^{85}$ "Contribution" is broadly defined, and specifically

77 Under s 21 of the 1976 Act, the court may declare that an agreement is wholly or partly ineffective, either because of non-compliance with the statutory formalities, or because it would be unjust to give effect to the terms of the agreement. In considering the potential injustice of the agreement, the court must have regard to its provisions, the time that has elapsed since it was entered into, whether it was unfair or unreasonable at the time it was entered into, or whether it has become unfair or unreasonable because of a change in circumstances.

$78 \mathrm{~S} 8$.

79 S 9(4).

80 See the comments of Richardson J in Reid v Reid [1979] 1 NZLR 572, 611, and also the comments of the Minister in the second reading of the Matrimonial Property Bill (408 New Zealand Parliamentary Debates, 4565).

$81 \mathrm{~S} 11$.

82 This is defined as a marriage of less than three years duration (s 13).

$83 \mathrm{~S} 14$.

${ }_{84} \mathrm{~S} 14$.

$85 \mathrm{~S} 15$. 


\section{Northern Ireland Legal Quarterly [Vol. 53, No. 1]}

includes both financial and domestic contributions, the forgoing of a higher standard of living which would otherwise be available ${ }^{86}$ and the giving of assistance or support to the other spouse, whether or not of a material kind. ${ }^{87}$ Assistance or support specifically includes help that enables the other spouse to acquire qualifications ${ }^{88}$ or that aids him in his occupation or business. ${ }^{89}$ Monetary contributions are not presumed to be more valuable than nonmonetary ones..$^{90}$

Hence, although the 1976 Act primarily enforces a community property approach, a place remains for the exercise of judicial discretion, where equal distribution would be manifestly unjust. ${ }^{91}$ However, rather than a full supplementary power of equitable redistribution, where the court might redistribute the property as it thought just, the redistribution must be based on "contribution" to the relationship. This clearly derives from the communitarian emphasis on sharing and partnership, where the emphasis on equality is based on a belief that equal contributions are made by both spouses. Nevertheless, it shares important features with equitable redistribution powers, as prevailing in other jurisdictions, particularly in the listing of a wide range of factors that can be taken into account in determining the "contribution" of each spouse. ${ }^{92}$

The Act operates on a "clean break" principle. On the breakdown of the relationship, the matrimonial property is divided between the former spouses, who are thereafter free from property claims by each other. A similar principle applies with regard to spousal maintenance proceedings under the Family Proceedings Act 1980. Generally speaking, spousal maintenance after the end of the marriage will be short-term only, and will be strictly needs-based. Maintenance will usually terminate on divorce, but this is not always the case, as it may continue where it is necessary to meet the reasonable needs of the other party, which cannot be met by the party herself. Inability to meet reasonable needs may arise from factors including custodial arrangements, the division of functions within the marriage or the need to undertake re-education or re-training to facilitate independence. ${ }^{93}$ Maintenance may also be continued if it is necessary to meet reasonable needs, and it would be unreasonable not to award maintenance, considering the ages of the spouses and the duration of the marriage. ${ }^{94}$ The impact that this restrictive approach to maintenance may have on the equality ideal will be discussed in the final sections of this paper.

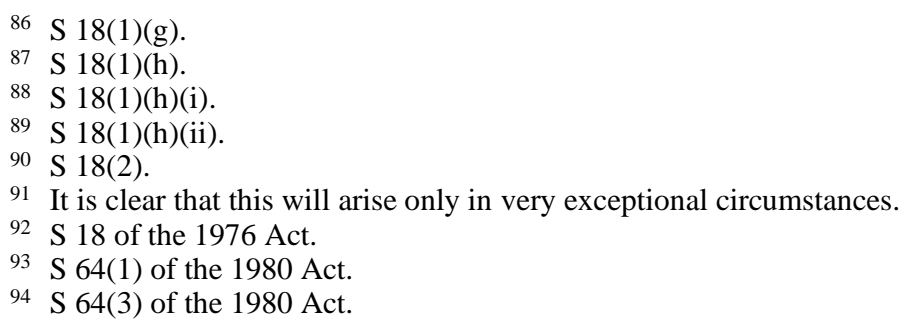




\section{Proposals For Co-Ownership Of Matrimonial Property In Northern Ireland}

In Northern Ireland, as in Ireland, it is generally presumed that the person who paid for property is the owner of it, and that the individual's property rights are not altered by marriage. However, under trusts law, a spouse (or other person) can acquire an interest in property by contributing to its acquisition. ${ }^{95}$ "Contributions" are strictly defined, and so-called "indirect" contributions (for example, the payment of household bills) will generally not suffice. ${ }^{96}$ This stringent approach is ameliorated by statutory provisions, one of the most important of which is the Matrimonial Causes (Northern Ireland) Order 1978. This confers on courts the power to transfer property between spouses in divorce, nullity and judicial separation proceedings, after considering a number of statutory factors. Other important rights include the statutory right of occupation in the matrimonial home, under the Family Homes and Domestic Violence (Northern Ireland) Order 1998. As yet, however, no automatic ownership rights are conferred on spouses in Northern Ireland, although this may be about to change following the recent recommendations of the Law Reform Advisory Committee for Northern Ireland (LRAC). ${ }^{97}$

The LRAC's recommendations are focused primarily on the family home, ${ }^{98}$ housekeeping money and household goods. Regarding household assets, the LRAC recommends that property acquired by either spouse, or both, or transferred by one to the other, for the joint use of the couple, should generally be jointly owned. This would be subject to exclusion by the parties, which would be established by the acquiring or transferring party making it known to the other party, at the time of the transfer or acquisition, that ownership was not being transferred. ${ }^{99}$ How this should be evidenced is not discussed in the report, and seems likely to be the subject of dispute.

Although the discussion in chapters 3 and 5 of the Report is focused on "household goods and housekeeping money", the scope of the actual recommendation made ${ }^{100}$ is such that almost any asset acquired for joint use or jointly purchased may come within the ambit of the rule. ${ }^{101}$ For example, a family car, though not usually understood as a "household good", may be covered by the rule. ${ }^{102}$ The main difficulty with the provision concerns the

95 McFarlane v McFarlane [1972] NI 59; $C$ v $C$ [1976] IR 254.

96 Unless there is an express agreement to the contrary; see McFarlane v McFarlane [1972] NI 59, and the general summary of the law contained in the Law Reform Advisory Committee Report below.

97 Matrimonial Property, Law Reform Advisory Committee for Northern Ireland Report No 10 (LRAC No 8, 2000) (hereafter "the Report"), which followed on Matrimonial Property, Law Reform Advisory Committee for Northern Ireland Discussion Paper No 5 (1999).

98 The term "joint residence" is used throughout the Report, as the Report also makes recommendations concerning certain co-habiting couples.

99 See para 5.12 of the Report.

${ }^{100}$ Recommendation 4 in Chapter 6 of the Report.

101 Excluding land, business assets, the joint residence, life assurance policies or contracts of deferred annuity.

102 This is a deliberate departure from Scottish law; see paras 5.10 and 5.11 of the Report. 
potential difficulties caused by equitable interests for third parties, particularly purchasers and creditors. It is not clear how extensive a doctrine of notice will be applied: for example, is a purchaser of property from a married person ${ }^{103}$ automatically put on notice that the vendor's spouse may be entitled to a joint equitable interest in that property? Indeed, what level of joint use is required to render an asset co-owned, and what level of enquiry by purchasers is required?

Greater difficulties may arise in the context of the family home. Emphasising that the female partner is historically and socially more likely to be disadvantaged with regard to property ownership, the LRAC recommends that a presumption of an equitable joint tenancy should apply to the couple's joint home. This presumption could be rebutted by an express agreement to the contrary by the parties, evidenced in writing. The presumption would not apply retrospectively, but would arise in every subsequent transaction involving the acquisition of a principal joint residence by a married couple, or by either spouse, or where a joint residence was put by either spouse into the name of the other. Retrospective application is rejected as being likely to interfere with prior agreements between spouses, and as being a disproportionate interference with property rights. ${ }^{104}$ Instead, where a situation is not covered by the proposed legislation, it is recommended that the court should be directed to consider a number of factors in determining the parties' respective beneficial interests in the property. ${ }^{105}$

Although the LRAC gives reasoned arguments in support of its proposals, the result is unfortunate. As between spouses, a two-tier system is proposed, whereby older wives, in established homes, are unlikely to benefit from the new system. Given that these wives are likely to be those most involved in "traditional" marriages, it seems strange that they are least likely to benefit from the proposals, while younger wives, who are more likely to be earning, and to acquire their homes jointly with their spouses, are covered by the proposed new rules.

Admittedly, older wives would come within the LRAC's alternative system, and might be awarded a beneficial interest in the home under the criteria contained in paragraph 5.34 of the Report. These generally relate to contributions "in money and money's worth", but the nature of these contributions is not specified. In particular, does a contribution "in money's worth"106 include work in the home and childcare, and if so, how is the value of these contributions to be quantified? Previous experience in other jurisdictions (for example, New Zealand) does not suggest that much value is placed by the judiciary on contributions of this type. ${ }^{107}$ Similarly, what exactly are the "reasonable expectations of the parties in all the circumstances of the case" 108 , and how are they to be assessed and

\footnotetext{
103 Or a co-habiting one, within the meaning of the Report.

104 See para 5.25 of the Report.

105 See paras 5.32 to 5.34 of the Report.

106 Para 5.34(a) of the Report.

107 See Peart, "Towards a Concept of Family Property in New Zealand" (1996) 10 Int'l J. of Law, Policy and the Family 105 at 112.

108 Para 5.34(f) of the Report.
} 
quantified? Is this a purely objective criterion, or is there a subjective element?

Although some of the stated criteria may be helpful in expanding the restrictive approach of equity, many of the factors listed in the Report seem likely to lead to further difficulties, despite the LRAC's views to the contrary. ${ }^{109}$ While considerations of beneficial entitlement may be overlooked in the marriage breakdown context, as the court may then utilise its power to adjust property rights, ${ }^{110}$ it is likely that much less protection will be afforded to "traditional" wives in the context of bankruptcy or the repossession of property. Difficulties may also arise for creditors, with regard to the taking or realisation of a secured interest in the family home. ${ }^{111}$ Many of these difficulties could be avoided by a deferred community approach, which would generally not affect third party rights, would eliminate the need to determine whether an asset was acquired for joint use, and would generally avoid the complications of potential equitable interests. As against this, a spouse in a deferred community regime would have no property entitlements until the termination of the marriage, and might therefore be deprived of the psychological advantage of financial power during the marriage. A deferred community regime would therefore fail to give a spouse priority over third parties, including creditors, as the LRAC's proposals might do.

\section{Separation of Assets, Equitable Redistribution And Irish Law}

In Ireland, as in Northern Ireland, the basic separation of assets approach is modified by trusts law. In this regard the Irish courts have permitted a greater degree of latitude in the interpretation of what amounts to a contribution, than the judiciary in Northern Ireland. ${ }^{112}$ However, many of the applicable rules can still seem rigid and illogical. ${ }^{13}$

Finding a pre-existing proprietary interest is no longer necessary between spouses as the strict principles of separation have been ameliorated by the

109 Para 5.35 of the Report.

110 The Report does not state that the new joint ownership system would replace the equitable redistribution system currently in place, and therefore it is assumed here that the proposed new provisions would be in addition to the existing provisions.

111 For a more complete discussion of this issue, see Fox, "Co-ownership of Matrimonial Property: Radical Proposals for Reform" (2001) 52 NILQ 20 at 43.

112 E.g., an indirect financial contribution to a family fund, which enables the owning spouse to pay the mortgage, is a sufficient contribution, unless the contrary has been agreed. $M c C$. v McC. [1986] 6 ILRM 1.

113 E.g., contributions to "improvements" generally do not count as contributions to the acquisition of property, but as a gift to the landowner: $N A D$ v TD [1985] 5 ILRM 153. Work contributions in the husband's business may have a monetary value, but work in the home does not, as it is something the wife might be expected to do in any event (see Mee, "Trusts of the Family Home: the Irish Experience" (1993) Conv 359 at 366). Even where a wife has contributed by work, it may be insufficient to obtain a share, even if this was intended by both parties: see $C R$ v $D R$ (High Court, unreported, April 1984) and Shatter's comments thereon (Shatter, Shatter's Family Law (4th ed, 1997) (hereafter "Shatter"), p 803). 
principles of equitable redistribution through a range of recent enactments. ${ }^{114}$ Under the new legislation, ownership is acknowledged, yet may be deemed unjust or unsatisfactory, considering the circumstances of the case. ${ }^{115}$ Indeed, it seems that strict separation principles are now so adulterated that in many respects the parties' respective assets form one almost homogeneous mass, ready for appropriate division. ${ }^{116}$ Although the legislature has provided some degree of guidance as to how this division should occur, ${ }^{117}$ there remains a high degree of uncertainty: no spouse can be sure of his or her rights until the court has spoken, and even then, it is clear that no form of closure can be relied on. ${ }^{118}$ Finally, although the principles of equitable redistribution may be said to be based on some of the same ideas as community of property (most notably, the view that there is an economic partnership between the spouses), this partnership is usually only given effect when the marriage ends, with the result that there is no equality between the spouses until that time, and perhaps not even then. ${ }^{119}$

Currently, where spouses disagree, separate or divorce, the court may make ancillary orders, including property adjustment orders and lump sum payment orders, under the Judicial Separation and Family Law Reform Act 1989, the Family Law Act 1995 or the Family Law (Divorce) Act $1996 .{ }^{120}$ The relevant provisions contained in the 1989 Act were repealed and replaced by the 1995 Act, which applies in the context of any judicial separation proceedings instituted after the commencement of that Act. ${ }^{121}$ The court's powers are very extensive; orders might include the sale of property and division of the proceeds (not necessarily in proportion to ownership of the property), or ordering one spouse to transfer his or her interest in

114 The Judicial Separation and Family Law Reform Act 1989, the Family Law Act 1995 and the Family Law (Divorce) Act 1996.

115 As opposed to a trusts analysis, where it is concluded that property is not owned as per the legal title.

116 See the comments of Lord Denning in the English case, Hanlon v The Law Society [1980] 1 All ER 763 at 770. In Ireland, the parties' pre-existing property rights are merely one factor among many for consideration, albeit one that many courts emphasise.

117 See below.

118 See, e.g., J.D. v D.D. [1998] FLJ 17. In the High Court, McGuinness J commented that by enacting the 1996 Act, the legislature "has made it clear that a "clean break" situation is not to be sought and that, if anything, financial finality is virtually to be prevented. . " S 22 of the 1996 Act and s 18 of the 1995 Act explicitly confer on the court almost unlimited powers to vary, suspend or terminate earlier orders, excluding only a few situations where limited blocking orders may be made (e.g. in relation to settlements).

119 Obviously, a similar criticism may be made of a deferred community system, although there, spouses are at least aware of their future entitlements.

120 This article concentrates on the property adjustment and lump sum provisions contained in the legislation, but other orders affecting property may also be made. These include financial compensation orders, by which the court may make provision for the future financial security of a spouse, and compensate her for financial loss, by means of insurance policies. Maintenance orders, pension adjustment orders, and miscellaneous ancillary relief orders are also available.

121 The property provisions of the 1989 Act are now effectively irrelevant in practice, as they apply only in very limited circumstances (s 3(2)(c) of the 1995 Act). 
property entirely to the other. ${ }^{122}$ However, in applying the legislation, the courts have tended to have regard to the extent of the parties' pre-existing rights: for example, a court might not be willing to transfer the entire interest in the family home to one spouse, but might transfer the outstanding share to a spouse who is already entitled to a partial interest. The quantification of the parties' relevant shares in the property therefore remains relevant, as this can affect the court's view of justice in any particular case. ${ }^{123}$

\section{The Irish Legislation In Practice}

A key question in Irish law is whether the courts are in fact taking advantage of the formidable array of powers currently at their disposal, and to what extent they are inclined to emphasise the legal ownership of the assets in question, rather than other matters such as the degree of sharing, moral support and contributions to home life which a non-owning spouse may have made during the marriage.

It is difficult to analyse judicial practice in this area, as there are comparatively few reported judgments. Many cases settle before hearing, ${ }^{124}$ orders are often consensual, ${ }^{125}$ judgments are mostly unwritten and contain little theoretical analysis, and the level of discussion of the relevant principles is generally not high. Even where a written judgment is available, it frequently fails to list or value all the assets available. It is therefore extremely difficult to establish exactly how property is distributed. Finally, given the comparatively recent nature of the 1995 and 1996 Acts, time must be allowed for a settled line of authority to emerge, although it would seem reasonable to expect a similar interpretation to the equivalent provisions in the 1989 Act. $^{126}$

In making ancillary orders, including property distribution and lump sum orders, courts are required to consider particular criteria. The key requirement in the 1995 Act is that the provision made must be "adequate and reasonable", ${ }^{127}$ while the 1996 Act states that "proper provision" should be made for the spouses and the children of the marriage. ${ }^{128}$ Neither phrase is defined, but both Acts list factors to which the court must pay particular

122 S 9(1)(a) of the 1995 Act and s 14(1)(a) of the 1996 Act. Coggans and Jackson comment that "[i]n practice orders under s 14 are most frequently made by way of a simple transfer of the property, usually the family home and contents, from one spouse to the other in consideration of a lump sum payment by the other spouse to the value of their [i.e., the transferor's] interest in the property, or a portion thereof depending on the transferee's ability to pay." See Coggans and Jackson, Family Law (Divorce) Act, 1996 (1998), p 37.

123 Compare, e.g., $E M$ v WM [1994] 3 FLJ 93 with $O^{\prime} L(A)$ v $O^{\prime} L(B)$ [1996] 2 FLJ 63, both discussed below.

124 Walls and Bergin, The Law of Divorce in Ireland (1997), p 101.

125 Clissmann, "Ancillary Relief Update" (Family Law in Ireland Conference, Dublin, 26 March 1998), p 24.

126 Different principles might well be thought to apply to a property division in the context of judicial separation, than in that of divorce. However, this is not the position adopted in Ireland.

127 S 16(1) of the 1995 Act.

128 S 20(1) of the 1996 Act. 
regard in reaching its decision. ${ }^{129}$ Relevant factors include the present or likely future "income, earning capacity, property and other financial resources" 130 and the "financial needs" 131 of each spouse. No order may be made unless it is in the interests of justice. ${ }^{132}$

Although potential earning capacity will be considered by the courts, ${ }^{133}$ it is clear that less stringent standards may well be applied where a home-making spouse is concerned. ${ }^{134}$ Equally, however, the court may be influenced by the need of a spouse to retain assets for a particular reason. Where wives are concerned, the asset tends to be the family home, and the need related to childcare; ${ }^{135}$ for husbands, the need may well be business related. ${ }^{136}$ The assets of both spouses will be viewed in their entirety, and the courts are not restricted to the assets acquired during the marriage; indeed, such matters as potential legacies or income from trust funds, at unspecified future dates, may also be taken into account. ${ }^{137}$

A key problem in Irish law is that the primary aim of the legislation is unclear. Although the criteria listed for judicial consideration are all legitimate, as Power notes with reference to the 1996 Act,

"What is missing is the bigger picture. What outcome are the criteria designed to achieve between the couple? To ask this is to speculate on the aim that underlies the making of orders and

129 Ss 16(2)(a) to 16(2)(1) of the 1995 Act and s20(2)(a) to 20(2)(1), and s 20(3) of the 1996 Act. These criteria apply where the applicant is a spouse. Other criteria apply where the applicant is a dependent family member.

130 S 16(2)(a) of the 1995 Act, and s 20(2)(a) of the 1996 Act.

$131 \mathrm{~S} \mathrm{16}(2)(\mathrm{b})$ of the 1995 Act and s 20(2)(b) of the 1996 Act.

$132 \mathrm{~S} 16(5)$ of the 1995 Act and s 20(5) of the 1996 Act.

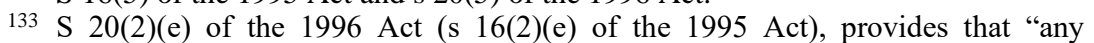
physical or mental disability" of either spouse is a matter to be considered by the court. In S.B. v R.B. [1996] IFLR 220, the wife's medical condition, which made it difficult to earn any substantive income, was taken into account by the court in reaching its decision.

134 In B.F. v V.F. [1994] 1 FLJ 15, it was held that it was "reasonable and proper" for the wife not to seek work outside the home "at present", as she was providing a home for the three children of the marriage, "a full-time occupation in itself."

135 Ward, for example, regarding a sample of District Court maintenance applications, noted that $86 \%$ of wives had dependent children living with them at the time of the application. See Ward, Financial Consequences of Marital Breakdown (1990), p 27: hereinafter referred to as "Ward (1990)". S 20(2)(j) of the 1996 Act $(\mathrm{s} \mathrm{16}(2)(\mathrm{j}), 1995)$ requires the court to have particular regard to "the accommodation needs of each spouse," and s 15 (s 10, 1995) also requires that "proper and secure" accommodation should be provided, where practicable, for a spouse who is wholly or mainly dependent on the other, and for any dependent children. However, the wife may simply be given occupational, rather than ownership rights (e.g. until the children leave the home), or indeed, the home may be sold, and the proceeds divided to allow for new accommodation to be acquired; $A O^{\prime} L$ v $B O^{\prime} L$ [1996] 2 FLJ 63.

136 In J.D. v D.D. [1998] FLJ 17, it was held that the husband's need to retain a sufficient working capital for his business as an auctioneer meant that $£ 160,000$ should be left in the business.

137 E.g., in J.D. v D.D., ibid, McGuinness J held that the court could take account of the husband's likely allocation of money from a family trust fund, and the high degree of unlikelihood of a similar allocation being made to the wife. 
there is little legislative guidance on this, except that, whatever the aim is, it must be proper in the circumstances". ${ }^{138}$

Overall, the greatest emphasis appears to be placed on the needs of the parties at the time of the application, as opposed to the making of a fair overall distribution based on the respective contributions to the marriage. ${ }^{139}$ However, it is probable that this depends on the circumstances of the parties: the greater the degree of wealth, the likelier a redistribution of assets, both because more is available, and because the parties may have higher expectations and standards of living. ${ }^{140}$ There appears to be quite a high degree of judicial realism here; the courts have noted that in most property divisions in the event of marriage breakdown, there is very little to go around, and that it is likely that all parties will end up less well-off than before. ${ }^{141}$ It should not be forgotten that the main emphasis in many cases will be on obtaining sufficient maintenance, rather than on a division of assets, although the high degree of non-compliance with maintenance orders $^{142}$ may well incline the courts toward making a lump sum provision, where possible.

The court must also have regard to the spouses' ages, the duration of the marriage, and the length of time that they lived with one another. ${ }^{143}$ These factors may be significant in two respects: the duration of the partnership may lead to a presumption that a higher degree of sharing is appropriate, and the older the spouses are, the less their earning capacity may be. ${ }^{144}$ A woman who has spent her life as a homemaker may be an unsuitable candidate for the job market, due to market competition and lack of training, and it may also be unfair to expect her, at a late stage of her life, to reverse all the

138 Power, "Maintenance: No Clean Break with the Past" [1998] 1 IJFL 15 at 16.

139 S 20(2)(b) of the 1996 Act also requires the courts to have regard to actual and potential "financial needs, obligations and responsibilities" of each spouse, including needs arising in the case of remarriage (s 16(2)(b) of the $1995 \mathrm{Act}$ ).

140 S 20(2)(c) of the 1996 Act also specifically requires the court to consider the standard of living previously enjoyed by the family or spouses (s 16(2)(c) of the 1995 Act).

141 See, e.g., R.H. v N.H. [1986] ILRM 352 and B.F. v V.F. [1994] 1 FLJ 15.

142 See Ward (1990), supra n 135, p 35. Ward found that, of a large sample of District Court maintenance orders paid through the District Court Clerk, 28\% were never paid at all, $49 \%$ were more than six months in arrears, $10 \%$ were in arrears for less than six months, and only $13 \%$ were fully paid up. Overall, $77 \%$ of all maintenance orders were in arrears for over six months. However, as noted

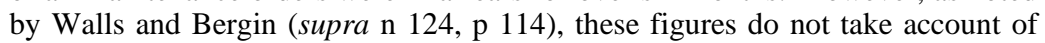
situations where maintenance is agreed informally by the parties, or in a separation deed, or where the order is made by the Circuit Court or High Court. See also the comments of Fahey and Lyons on Ward's analysis: Fahey and Lyons, Marital Breakdown and Family Law in Ireland: a Sociological Study (1995), p 85.

143 S 20(2)(d) of the 1996 Act (s 16(2)(d) of the 1995 Act).

144 S 20(2)(g) of the 1996 Act requires the court to consider the "effect on the earning capacity of the spouses of the marital responsibilities assumed by each," especially where these duties have resulted in one spouse having "foregone the opportunity of remunerative activity" (s 16(2)(g) of the 1995 Act). In $D$ v $D$ (Supreme Court, unreported, July 1991), the wife's share was increased because she had sold her own business at her husband's request, on marrying him 28 years before. 
expectations and decisions on which her life has, until then, been based. However, an elderly spouse may also have a low life expectancy, with the result that a moderate capital provision may be sufficient for her needs. ${ }^{145}$ Finally, where a marriage is of short duration, a court would probably be reluctant to grant a share of the other spouse's property, especially where it was acquired prior to the marriage.

Section 20(2)(f) of the 1996 Act $^{146}$ requires the court to have regard to:

"the contributions which each of the spouses has made or is likely in the foreseeable future to make to the welfare of the family, including the contribution made by each of them to the income, earning capacity, property and financial resources of the other spouse and any contribution made by either of them by looking after the home or caring for the family."

The contributions to be evaluated do not only relate to the past, but may be potential or future (for example, continued childcare responsibilities). This statutory emphasis on the homemaker's contributions contrasts starkly with the judicial position adopted in the law of trusts, where work in the home clearly does not constitute a contribution to the home's acquisition. ${ }^{147}$ Presumably, the legislature was justifiably apprehensive as to the consequences if no express stipulation of this kind were included, although individual judges have expressed a sense of the value of the homemaker's contributions. $^{148}$ Indeed, a similar provision had been included in the 1989 Act, ${ }^{149}$ clearly demonstrating a gradual shift in emphasis from purely financial considerations to evaluating the role of both parties in a broader light.

Although the courts have the power to take such factors into account, to what extent are they willing to do so? It is clear that merely empowering judges to take note of homemaking contributions will not necessarily result in weight being given to them, particularly where the bulk of the family property is owned by the other partner. In New Zealand, difficulties arose in applying a similar provision of the Matrimonial Property Act 1963, which specified that the court could have regard to contributions in "money payments, services, prudent management or otherwise howsoever". Despite the clear aim of acknowledging the contributions of home-making spouses, the provision was

145 See, e.g., Page v Page [1981] 2 FLR 198.

$146 \mathrm{~S} 16(2)(\mathrm{f})$ of the 1995 Act.

147 See, e.g., R.K. v M.K. (High Court, unreported, 24 December 1978). One of the principal difficulties here is that of measuring the monetary value of work in the home. With regard to the 1996 Act, Shatter (supra n 110, p 829, n 587) comments that "the courts have not in practice specifically spelt out an applicable methodology for determining the exact monetary value of such contribution but have merely regarded it as one of the statutory factors together with others to be taken into account. . ."

148 See, e.g., Lord Denning MR's comments in Wachtel v Wachtel [1973] 1 All ER 829 , or the comments of Barr J in the High Court decision in $L \vee L$ [1989] ILRM 528. The recent House of Lords decision in White v White [2001] 1 AC 596 recently affirmed the equal significance of financial and domestic contributions. See the speech of Lord Nicholls at 605, and also the comments of Lord Cooke, regarding previous judicial attitudes to non-financial contributions (at 613).

149 S 20(2)(f) of the 1989 Act and s 16(2)(f) of the 1995 Act. 
restrictively interpreted, and domestic contributions were conservatively valued. ${ }^{150}$ Similar difficulties have arisen in England and Wales, ${ }^{151}$ although these may now have been resolved by the recent House of Lords decision in White v White. ${ }^{152}$ Affirming the value of both domestic and financial contributions, Lord Nicholls commented:

"... [W] [Watever the division of labour chosen by the husband and wife, or forced upon them by circumstances, fairness requires that this should not prejudice or advantage either party when considering. . . the parties' contributions. . . If, in their different spheres, each contributed equally to the family, then in principle it matters not which of them earned the money and built up the assets. There should be no bias in favour of the money-earner and against the home-maker and carer". ${ }^{153}$

In Ireland, the weight given to non-financial contributions varies with the court. ${ }^{154}$

The conduct of the spouses may also be taken into account, if the court is of the opinion that it would in the circumstances be unjust to disregard it. ${ }^{155}$ "Conduct" would presumably include adultery and cruelty, ${ }^{156}$ so that this stipulation sits strangely with the "no fault" concept of divorce enshrined in the legislation and the Constitution. The significance of conduct such as adultery may vary with the facts and with the court. However, it seems reasonable that where divorce means that both parties are financially worse off, the party at fault should to some extent bear the cost of the loss induced by his or her conduct. ${ }^{157}$ Finally, the "rights of any person other than the spouses, including a person to whom either spouse is remarried" may also be

150 See, e.g., Peart, supra n 107. This difficulty led to the specific granting of equal weight to domestic contributions in the Matrimonial Property Act 1976.

151 Walls and Bergin, supra n 124, p 103.

152 [2001] 1 AC 596.

153 Ibid, at 605. Although the court emphasised that there was no presumption of equal division, it noted that there was now "greater awareness of the value of nonfinancial contributions to the family" (ibid), and addressed the need to reconcile fairness and the needs or "reasonable requirements" of the parties, and to avoid discrimination.

154 E.g., $J D$ v $D D$ [1998] FLJ 17 (discussed below).

$155 \mathrm{~S} 20(2)(\mathrm{i})$ of the 1996 Act and s 16(2)(i) of the 1995 Act.

156 In EP v CP (High Court, unreported, 27 November 1998), p 2, McGuinness J noted that the husband "showed no sign of regret for the breakdown of his marriage", which resulted from his adultery and desertion, and showed "very little sign of a real sense of responsibility for the upbringing and financial backing of his children".

157 In $M Y$ v $A Y$ [1997] 3 FLJ 86, Budd J cited with apparent approval a dictum of Costello J in $E D$ v $F D$ (High Court, unreported, 23 October 1980) that a husband who deserted his family should be the one to suffer a fall in income, if this was necessary to protect the financial position of the wife and children. Similarly, in $B(S) \vee B(R)$ [1997] 3 FLJ 66 at 69 , McGuinness J felt that the husband's adultery was a relevant factor in the apportionment of assets, although in her decisions in $A F \vee E F$ (Circuit Court, unreported, May 1995) and $E M \vee W M$ [1994] 3 FLJ 93, she held that, on the facts, it was not. However, in the last mentioned decision, the husband's financial conduct and long history of nonpayment of maintenance was taken into account (ibid at 96). 
considered by the court, ${ }^{158}$ as may the terms of any separation agreement the couple have entered into, where that agreement is still in force. ${ }^{159}$

As noted previously, it is difficult to establish precise trends or principles in asset division, given the dearth of reported cases in this area. However, a brief analysis of some of the leading cases clearly demonstrates that judicial views of "proper" provision, in terms of both maintenance and equitable redistribution of capital assets, are highly inconsistent. ${ }^{160}$ In $J D \vee D D$, McGuinness J held that the financial circumstances were such as to permit a lump sum provision as well as periodic maintenance. Given the length of the marriage, the lack of any career prospects for the applicant, the fact that the respondent was able to accumulate considerable wealth during the marriage due to the low level of matrimonial expenditure, the applicant's work in the home, and the fact that her role as homemaker was approved by the respondent, McGuinness J felt that a "reasonably equal" distribution was appropriate. She therefore ordered payment of a lump sum by way of maintenance of $£ 200,000^{161}$ to be paid to the applicant. ${ }^{162}$ A similar preference for equality was evident in $E P \vee C P .{ }^{163} \mathrm{Here}$, most of the family savings were agreed to have arisen out of work done by the husband, but this was because the household was apparently run on the wife's salary. Again, a reasonably even distribution was made by the court, with McGuinness J noting that "it was a joint enterprise and must be taken as such." 164

However, equality is not the sole guiding principle of the courts: other concerns include fairness, particularly to parties making financial contributions. In $O^{\prime} L(A)$ v $O^{\prime} L(B),{ }^{165}$ a judicial separation case, McGuinness $\mathrm{J}$ was strongly influenced by the fact that "virtually all of the financial contributions" to the family home came from the husband, ${ }^{166}$ although the wife had made some indirect contributions from her savings, and had given up her career to care for the child and the home generally. McGuinness J commented that, from a point of view of justice, "[A] proposal simply to

158 S 20(2)(1) of the 1996 Act. No equivalent provision was contained in the 1989 Act, although (strangely) one is contained in s 16(2)(1) of the 1995 Act.

$159 \mathrm{~S} 20(3)$ of the 1996 Act. Clissmann fears that this sub-section "may mean that Courts will be more reluctant to act as generously in divorce cases where there is already a Separation Deed. . ." (Clissman, supra n 125, p 18). There is no equivalent provision in the 1995 Act, as where a couple have already concluded a separation agreement, they cannot avail of the statutory remedies otherwise available on separation.

160 The court will occasionally go beyond its strict statutory function by offering suggestions to the parties, in the interests of saving them from further costs. See the comments of Murphy $\mathrm{J}$ in $C(L)$ v $C(A)$ [1994] 1 FLJ 19.

161 All figures are in IEP unless otherwise stated.

162 [1998] FLJ 17 at 29. The respondent also undertook to discharge the outstanding cost of the applicant's residence, representing her share of the family home and contents. The family home was to remain in the respondent's name. Approximately $£ 160,000$ involved in the respondent's business was to be left there, to ensure its survival. The respondent's other assets were valued at approximately $£ 460,000$, while the applicant's amounted to about $£ 46,000$.

163 High Court, unreported, 27 November 1998, p 111.

164 Ibid, p 5 .

165 [1996] 2 FLJ 63.

166 Ibid at 66. 
transfer this entire asset to the wife gives no recognition to [the husband's] contributions and I do not feel that it would be equitable to take this course."167 Although the wife in this case was awarded maintenance and a lump sum (less than half the expected proceeds of the sale of existing property) to buy a new home, it is interesting to note the reluctance of McGuinness $J$ to transfer the house to the wife, because of the husband's financial contributions. This may reflect a trusts-based approach, as much as a concern with fairness or the wife's apparently poor powers of management. ${ }^{168}$ A similar concern for fairness is evident in $L(J) \vee L(J)^{169}$ where McGuinness $J$ placed considerable emphasis on the wife's "ungenerous" attitude in declining to contribute at all to the mortgage out of her savings, unless the house was put in her sole name. ${ }^{170}$

The issue of financial contribution was also evident in $M(E) \vee M(W){ }^{171}$ Here, the family home, which was the sole asset of any value, was in the husband's sole name. However, at the time of trial, it was established that $65 \%$ of the beneficial ownership lay with the wife, who had single-handedly supported the family for many years. McGuinness $\mathrm{J}$ felt it appropriate to take account of the financial conduct of the husband, specifically, "his noncontribution to the mortgage and his failure over many years to assist in the maintenance of his wife and children". ${ }^{172}$ Under the 1989 Act, improvements made by both parties could also be considered, ${ }^{173}$ and here the husband's contributions were of little lasting value, or were made with money he had not repaid, while the wife's were "considerable". ${ }^{174}$ McGuinness J therefore held that it was equitable to transfer the outstanding $35 \%$ of the home to the wife, making her sole owner, subject to various charges.

In other cases, the proportions of distribution are unclear. In $S B \vee R B,{ }^{175}$ the distribution of the proceeds of sale of the house favoured the wife and child, but the total disposable assets are unspecified in the judgment. Occasionally, a serious disproportion exists. In $B F \mathrm{v} V F,{ }^{176}$ a separation case, the wife ended up with a net income of $£ 23,000$ (including maintenance) to support herself and the three children of the marriage, leaving the husband with about $£ 33,000$ net for his sole use. ${ }^{177}$

$167 \mathrm{Ibid}$, at 67

$168 \mathrm{Ibid}$, at 66

169 [1996] 1 FLJ 36.

170 Ibid at 38.

171 [1994] 3 FLJ 93.

172 Ibid at 96

173 These could not be considered in assessing the existing beneficial entitlements of the parties.

174 [1994] 3 FLJ 93 at 96.

175 [1996] IFLR 220.

176 [1994] 1 FLJ 15.

177 The wife was also entitled to a lump sum order for $£ 14,000$ to compensate her for having to discharge bank debts, which arose out of her inability to make ends meet. Lynch J held that this, together with the assignment of the husband's lump sum on death or retirement, and the provision of an encumbrance-free two-bed apartment, was sufficient under the legislation. 
In some situations, it is clear that the court is more concerned with meeting bare needs, rather than with equality or fairness. In $Y(M) \vee Y(A),{ }^{178}$ Budd $\mathrm{J}$ noted that it was difficult to assess the husband's financial situation with any degree of accuracy, but that it was apparent that he earned "infinitely more than was disclosed", and that he was "well capable of providing the relatively small sums which his wife and child require to live on in a frugal and thrifty manner", while still having "substantial sums with which to indulge his own extravagant lifestyle."179 The wife had a very low income, and all her requirements were reasonable. Budd $\mathrm{J}$ noted that:

"[S]he does not socialise and clearly the sum of money which she and her son have to live on is inadequate. Meanwhile her husband enjoys an extravagant lifestyle living with his employee in London. . . He usually drives a large car and stays in expensive hotels and enjoys flying, shooting and scuba-diving as hobbies". ${ }^{180}$

It was estimated that the husband was earning about $£ 5,000$ per week, in part thanks to the wife's assistance in building up the business, and Budd J found that there was an intention on both sides that she would be entitled to a share in the assets and profits of the business. He ordered payments to the wife to provide her with $£ 800$ per month disposable income in total. She was also to be paid $£ 26,000$ in respect of arrears of maintenance, a lump sum of $£ 85,000$ to buy a house, and about $£ 4,000$ in respect of other sums due. This total lump sum payment of about $£ 89,000$ was to be in satisfaction of the wife's interest in the husband's business and business assets.

The case is of interest as it is one of the few available High Court judgments in this area. Given the husband's apparently high income, it is perhaps surprising that the court was satisfied to leave the wife and child with sufficient funds for only a "frugal and thrifty" lifestyle. ${ }^{181}$ The maintenance awarded was particularly low, amounting to little over a twentieth of the husband's gross monthly income. Even the lump sums awarded were relatively low, considering that they were due for arrears of maintenance and in respect of the wife's share in what was apparently a very profitable business, and did not greatly reduce the husband's assets.

Although this may be an extreme case, it is noticeable that it is by no means an isolated one, although disparity of distribution may occasionally be concealed, rather than illuminated, by the available figures. In $M c A \mathrm{v}$ $M c A,{ }^{182}$ a recent High Court decision in this area, the wife was awarded $£ 1.2$ million in respect of her share of the family business, together with the family home, an apartment in Tenerife, a shop and another house. She also received a pension adjustment order giving her a $75 \%$ share of the husband's main pension (worth $£ 750,000$ ), business assets worth $£ 48,000$, periodic maintenance of $£ 4,500$ (not index-linked) and a lump sum of $£ 300,000$. The husband retained the second family home and an apartment, a less valuable pension, and the remaining $85 \%$ of the business (as well as the remaining

178 [1997] 3 FLJ 86.

179 Ibid, at 89.

180 Ibid.

181 Ibid.

182 High Court, unreported, 23 May 2000. 
$15 \%$ interest he was ordered to buy from his wife). He also had other businesses, which were not discussed in the judgment.

However, the apparent generosity of the award to the wife is reduced, when it is revealed that she had no assets other than her share in the business, while the husband had assets of $£ 2$ million, as well as the rest of a business valued at $£ 8$ million and an annual income of $£ 120,000$. The wife actually received comparatively little of the husband's property, as the court noted that the $£ 1.2$ million was money to which the applicant was entitled as of right (due to her contributions to the business), irrespective of her rights under the 1996 Act. The judgment does not set out the particular factors relied on by the court, and does not elucidate any general principles; the sole comment regarding the 1996 Act was that the factors contained in section 20 did not require repetition by the court. However, it appears from McCracken J's observations that he was particularly influenced by the fact that the business was largely built up by the husband, and that the wife, once she received her share of the value of the business, would not really need that much more. In addition, McCracken $J$ was concerned that placing too heavy an onus on the husband might potentially damage the business, to no one's advantage.

In $C N$ v $R N,{ }^{183}$ the wife had not worked outside of the home while the parties cohabited, but the family home, worth $£ 110,000$ at the time of trial, was owned jointly by both spouses. At the time of trial, the wife had sole occupation of the home, and was in receipt of Deserted Wives Benefit of about $£ 64$ per week. She was employed as a school traffic warden at a gross wage of about $£ 2,200$ per annum, although this was unlikely to continue for long due to her age and poor health. The husband was employed in a company valued at $£ 1,000,000$, of which he was a $25 \%$ owner. He was in receipt of a gross annual salary of $£ 30,000$, plus expenses and other benefits. His net monthly income was about $£ 2,300$, plus expenses. He had had several property dealings, and extensively maintained his current partner, even though she had her own means. As McGuinness J felt that the husband could not afford much more in the way of maintenance, she ordered the sale of the family home. The bulk of the sale proceeds was to be spent on a new house for the wife, in which the husband would be a joint tenant (as he had paid most of the mortgage on the original family home), and the remaining $£ 30,000$ was to be invested for the wife; this was described as a lump sum maintenance order. Gross annual maintenance of about $£ 7,000$ was also ordered.

Given the extreme disparity of income and apparent earning capacity of the parties, the division of property in this case is surprising. The wife essentially ended up with a right of residence in a $£ 70,000$ house, which would only become fully hers if her husband predeceased her. The maintenance awarded was extremely low, even allowing for the $£ 30,000$ lump sum award, given the length of the marriage and the wife's age, poor health and almost non-existent income. The husband, on the other hand, had a high salary, and could presumably have easily afforded a higher rate of maintenance, if he had spent less extravagantly on himself and on his new partner. This might also have been considered more appropriate as the case related to separation proceedings, rather than divorce.

183 [1996] IFLR 1. 
It is likely that judgments will become more transparent in the wake of the recent Supreme Court decision in $M K$ v JP (Otherwise SK), ${ }^{184}$ overturning a substantial High Court award to a former wife due to the lack of clear grounds for the decision. Remitting the matter to the High Court, McGuinness $\mathbf{J}$ stated that in deciding what was proper provision for the former wife, the court had to consider her financial needs, her role in caring for the couple's six children, the couple's separation deed and the fact that the man's entire wealth had been accumulated after the couple had separated. The Supreme Court was unable to decide if the High Court had exercised its jurisdiction correctly in making the order since no indication was given in the High Court judgment as to what regard the judge had to various factors in the Act, and emphasised that a judge "should give reasons for the way in which his or her discretion has been exercised in the light of the statutory guidelines." 185

Interestingly, McGuinness $\mathrm{J}$ stated that she doubted whether a policy of equal division of assets between spouses had ever been part of the common law in Ireland or England (as held by the High Court) and noted that the concept of a single capital payment to a wife to meet her "reasonable requirements" for the rest of her life had never been part of Irish law. However, she was not clear as to what guiding principles might apply in the legislative context, other than to emphasise the need to take account of the factors listed in the legislation, and to cite with apparent approval the recent dictum of Thorpe LJ in Cowan v Cowan ${ }^{186}$ that fairness rather than equality was the rule. Irish law therefore still lacks a detailed and authoritative exposition of what amounts to "proper" provision akin to the House of Lords decision in White $\mathrm{v}$ White. ${ }^{187}$

Overall, it is clear that views of "proper" provision may vary greatly, and it is difficult to predict what award will be made in any given circumstances. Much appears to depend on the constitution of the court, as well as on the financial needs and contributions of the parties. The question must therefore be asked, does Irish law, as currently applied, offer a just and equitable solution to the difficulties of property division in marriage breakdown? It is submitted that it does not.

\section{An Irish Community Of Property?}

Irish legislation does not give either spouse the right to a defined share of the family property. However, it does implement a principle that an individual's property is not entirely his or her own, in a family situation, and that it may be redistributed despite the owner's wishes or intentions. The substantive effect of these provisions is to treat the separate assets of the parties as a fund, from which limited amounts may be doled out to either party. ${ }^{188}$ This

184 Supreme Court, unreported, 6 November 2001.

185 Ibid, per McGuinness J.

186 [2001] 3 WLR 684 at 703.

187 [2001] 1 AC 596.

188 Or indeed to third parties, such as children or dependents - see, e.g., s 14(1) of the 1996 Act. 
principle has in fact been in place since the enactment of the Succession Act 1965 , which guarantees certain rights to a surviving spouse. ${ }^{189}$

The Family Home Protection Act 1976 also constitutes an early step in this direction. The aim of the Act is to ensure that a spouse does not suddenly discover that the family home has been sold or mortgaged without his or her knowledge. The Act does not give the non-owning spouse an interest in the family home, but provides that any sale, transfer or mortgage of the home without that spouse's prior written consent is void. ${ }^{190}$ Where consent is unreasonably withheld, the court may dispense with this requirement. ${ }^{191}$ The court can also make such order as it thinks proper to protect a family home where it appears that a spouse is engaging in conduct that may lead to the loss of an interest in the home, or render it unsuitable for habitation. ${ }^{192}$ However, the court can only intervene if it is satisfied that the spouse has the intention of depriving the applicant spouse or a dependent child of her residence in the home. ${ }^{193}$ Finally, the Act restricts the disposal of household chattels, as defined, in certain circumstances. ${ }^{194}$

The trend towards increasing the property rights of spouses is conscious, not accidental. ${ }^{195}$ As early as 1972, the Commission for the Status of Women recommended that the adoption of a community regime be considered, and the Second Commission for the Status of Women recommended that a community regime of some sort should in fact be adopted. ${ }^{196}$ Both Commissions were particularly concerned that a pure separation of assets approach could result in grave injustice to wives, particularly with regard to the family home. This concern was addressed by the Matrimonial Homes

189 Where a spouse dies testate, the surviving spouse is entitled to half or one third of the value of the estate (depending on whether there are also surviving children): Succession Act 1965, s 111. Under s 56 of the Act, the surviving spouse also has a right to have the family home appropriated to him or her, in full or partial satisfaction of any share to which he or she is entitled. Where a person dies intestate, the surviving spouse is entitled to all or half of the estate, again depending on whether there are also surviving children: s 67 of the 1965 Act.

190 S 3.

$191 \mathrm{~S} 4$.

$192 \mathrm{~S} 5$.

$193 \quad S$ v $S$ [1983] 3 ILRM 387.

194 S 9.

195 A similar trend is noted by Dewar with regard to English law, with the "familialisation" of trusts and real property law and a "nascent statutory regime" regarding the family home. See Dewar, "Land, Law and the Family Home" (hereafter "Dewar (1998)"), in Bright and Dewar, Land Law: Themes and Perspectives, $\mathrm{p} 328$. See also Peart's contention that family property law may be divided into three stages of development, a "support" stage, a "contribution" stage and a "relationship" stage (supra $\mathrm{n}$ 107). This last suggests that the relationship should itself give rise to real property rights, and is in place in New Zealand since the adoption of the Matrimonial Property Act 1976. It is suggested that Irish law is now also moving towards this stage of development.

196 Commission on the Status of Women, Report to the Minister for Finance (1972) p 177. The Commission's first report preferred a deferred community approach (though without any real analysis of the regimes discussed), but the Second Commission, which actually recommended a community regime be adopted, did not discuss what type of community this should be. See Second Commission on the Status of Women, Report to Government (1993), p 39. 
Bill 1993, which represents the clearest example of the move towards community. The Bill imposed equitable co-ownership of the matrimonial home by spouses, where a dwelling had been occupied by a married couple at any time since a specified date, ${ }^{197}$ and either or both of the spouses had an interest in the dwelling, other than in equal shares. Under clause 4 of the Bill, the equitable interest in the property would, in these circumstances, vest in both spouses as joint tenants, subject to exclusion by the court. Under clause 7 , a spouse could also make a written declaration that clause 4 should not apply to the matrimonial home, after obtaining independent legal advice. Finally, clause 14 provided that the household chattels owned by either or both of the spouses would belong to both as joint owners. This provision could also be excluded by an agreement to the contrary.

On referral to the Supreme Court by the President, ${ }^{198}$ the Bill was held to be unconstitutional. Although the court accepted that the objective of the legislation was to promote the stability of marriage and the institution of the family, by encouraging joint ownership of the family home, the manner in which this objective was to be achieved conflicted with the inalienable right of decision-making reserved to the family itself under Article 41.1.1 of the Constitution. The Bill applied the principle of joint ownership to every matrimonial home, even though the couple living there might well have decided that the home should not be jointly owned. It therefore had the potential to interfere with positive decisions of the family. Even though the parties could still contract out of the legislation, it would be necessary for the couple to re-address the issue, which might arouse discontent and disturb the equilibrium of the family. The non-owning spouse might refuse to make a written declaration that the legislation would not apply, which could lead to litigation. ${ }^{199}$

However, it appears implicit in the Supreme Court's decision that not all attempts to establish such a regime would fail. The Court's emphasis was clearly on the impermissibility of legislative interference with past family decisions regarding ownership, and the automatic deprivation of proprietary interests that would ensue. It is not stated that legislation relating to the future acquisition of property by married couples would also be prohibited, particularly if the parties retained the option of contracting out of the statutory regime. ${ }^{200}$ There would thus appear to be nothing to prevent the imposition of a default system of community property, in relation to couples entering marriages in the future or, probably, in relation to the acquisition of new assets by couples already married. ${ }^{201}$ However, the result of this might

19725 June 1993.

198 Under art 26 of the Irish Constitution, the President may refer a bill to the Supreme Court to rule on its constitutionality. If found to be unconstitutional, the Bill cannot be signed into law.

199 Re Matrimonial Homes Bill 1993 [1994] 1 ILRM 241.

200 See Coughlan, "Land Law", in: Annual Review of Irish Law (1994), p 320.

201 This is less certain, as it might be held that a couple's implicit or explicit decision regarding the acquisition of property at the commencement of the marriage, could not be overridden by the legislature at a later date, even if the couple could opt to avoid the application of the legislation (note the Supreme Court's reluctance to cause family disputes). The difficulty of ascertaining the ownership of household 
well be the creation of a two-tier system of property ownership, whereby parties to earlier marriages would be less protected than those entering later marriages. This difficulty is likely to be particularly significant given that it is typically wives in "traditional" marriages who are most vulnerable financially. The decision also casts doubt on the constitutionality of the property adjustment orders which may be made by the courts under the 1989 and 1995 Acts, since these might well interfere with agreements regarding property ownership previously made by spouses. ${ }^{202}$

\section{Arguments For And Against Community}

To date, the focus in Ireland has been on ameliorating existing rules, rather than on revising the nature of the system itself - on remedying individual instances of injustice, rather than on providing a prescription for the just ownership of marital property. Should, therefore, the State intervene to impose a community regime in the context of matrimonial property?

Against the concept of community, it can be argued that the interference with family property rights and agreements is too great, and that it is not for the State to intervene to this extent. However, this argument can no longer withstand objective scrutiny, since the State already intervenes, in a far greater and less certain manner, in its equitable redistribution mechanisms. ${ }^{203}$ The statutory powers briefly analysed above clearly go far beyond the scheme outlined in the Matrimonial Homes Bill 1993. The only distinction appears to be that the Bill was certain in its scope and application: as noted above, the principal difficulty associated with the current law is its potential for arbitrariness and uncertainty.

Indeed, when the policy behind the current legislation is examined, it is clear that legislative policy has long moved towards community principles. The Succession Act 1965 already curtails the spouses' freedom of testamentary disposition, the Family Home (Protection) Act 1976 effectively restricts the right of sale of the family home (though without varying the ownership), and the 1989, 1995 and 1996 Acts permit redistribution of all property owned or likely to benefit either spouse. It is submitted that putting this intervention on a precise and formalised legal footing would not conflict with statutory policy; indeed, it might well be regarded as the culmination of such interventionism. It would also eliminate the inconsistency of rights being automatically granted on death, being awarded on a discretionary basis in the event of marriage breakdown, and not awarded at all while the relationship

chattels would also arise, as these would be likely to be acquired over a long period.

202 The 1996 Act is more secure, as the constitutional amendment which was necessary to permit the introduction of divorce legislation specifies that a dissolution of marriage may only be granted where "such provision as the court considers proper having regard to the circumstances exists or will be made for the spouses, any children of either or both of them and any other person prescribed by law" (Art 41.3.2.iii of the Constitution).

203 Indeed, in the English context, Dewar goes so far as to argue that "ownership now plays a default role", and is only relevant where there is no statutory means to resolve property disputes. See Dewar (1998), supra n 195, p 330. 
subsists. ${ }^{204}$ It would also help to eliminate the inordinate delays and consequent legal costs currently bedevilling Irish law. ${ }^{205}$

One of the strongest arguments in favour of a discretionary system is the flexibility it offers to deal with individual cases, and thus to maximise individual justice. This flexibility may indeed play an important role in cases where there is insufficient wealth to provide for all parties, and in particular to provide for the future of the children of the marriage. It may also be necessary to achieve long-term justice and equality between the parties. ${ }^{206}$ However, the price for this individual flexibility may be high, in terms of lack of foreseeability and certainty, and possibly with regard to difficulties in reaching a settlement between the parties. ${ }^{207}$ There is also, as Dewar points out, growing doubt as to our ability to know what is "best" in any particular case, partly because it is impossible to predict the future with certainty, and partly because it is by no means certain that the law is able to devise the most beneficial solution to a given set of facts. ${ }^{208}$

It is submitted here that the lack of principle and predictability are by no means outweighed by the flexibility of the current system. ${ }^{209}$ The evidence to date suggests that although some decisions implement a reasonably equal distribution of assets, in other situations courts are reluctant to utilise their statutory powers fully. Whatever a community of property lacks in the way of responsiveness, it at least offers a certain and principled solution to the ownership of marital property. ${ }^{210}$ Dependent spouses would be guaranteed a particular portion of the family assets, and would be less subject to the perils of litigation. The scope for arbitrariness would be removed, and the impact of what may sometimes appear to be conservative judicial attitudes would be reduced.

It is not suggested that parties should be unable to contract out of such an arrangement; on the contrary, they should always be able to do so, after obtaining independent legal advice. ${ }^{211}$ Moreover, the question of property ownership would at least have been raised and (presumably) discussed. ${ }^{212}$

204 The courts' powers under the 1995 Act are an exception to this general rule.

205 Fahey and Lyons found that the median duration of family law cases was between 12 and 19 months, with some cases lasting more than 3 years (supra n 140, p 94). Note also the regrets of McGuinness $\mathrm{J}$ in $E P$ v $C P$, where she commented that "The end result of this unfortunate history is that the considerable pot of capital which was available at the beginning of this case to both parties and for the future of their children is now dissipated either in borrowings or in legal costs. . . It is a tragedy that all of this money should have disappeared." (High Court, unreported, 27 November 1998, p 4).

206 See Wilson, "Ancillary Relief Reform" [1999] Fam Law 159 at 160.

207 See Rheinstein, "Division of Marital Property" (1976) 12 Williamette LJ 413 at 432.

208 Dewar, "Reducing discretion in family law" (1997) 11 AJFL 309 at 320.

209 For an opposing viewpoint, see Wilson, supra $\mathrm{n} 206$.

210 Interestingly, Dewar notes that there is no hard evidence that increased certainty would lead to reduced overall costs (to the State or the parties); this is an issue meriting further empirical research. See Dewar, supra $\mathrm{n} 208$.

211 For potential policy and practical difficulties here, see Wilson, supra n 206, at 162.

212 Strangely, the Law Commission for England and Wales, in its First Report on Family Property: A New Approach (1973) (Law Com No 52), cited this as an 
Since some intending spouses might be reluctant to insist on obtaining a share of the family property, it is suggested that where a regime of separation is selected, the equitable redistribution power should be retained. ${ }^{213}$ This would safeguard the family as a whole, in accordance with what is clearly legislative policy.

Of course, marriages where there was little property to be distributed would not be greatly affected, but these are in practical terms not much affected by the current legislative provisions either. ${ }^{214}$ Certainly, it is doubtful if a community regime would offer any advantages to the least well-off members of society. ${ }^{215}$ For this reason, the Law Commission for England and Wales considered that no purpose would be served by adopting a full community regime, and that joint ownership of the family home would serve just as well, as this was usually the only asset of any value. ${ }^{216}$ Shatter, on the other hand, noting the rise in joint ownership of the family home and the high level of statutory protection now afforded to spouses, contends that measures such as the failed Matrimonial Homes Bill (and presumably, a community of property) are consequently no longer necessary to safeguard spouses.217 However, he admits that circumstances may still arise where the non-owning spouse (generally the wife) will be vulnerable. ${ }^{218}$ It is submitted here that the fact that a proportion of the population would not necessarily obtain any advantage from a new property regime, does not justify ignoring the significant proportion that might do so.

More perturbing is the possibility that a community regime might work against vulnerable spouses, by limiting the fund for distribution on the termination of the relationship. Under current law, all assets owned by either party, or indeed, assets likely to be acquired by them, may be divided by the court. In the forms of community regime most likely to be adopted, a spouse only obtains an interest in the assets or gain acquired after the marriage. This could potentially preclude the division of a large portion of wealth. However, this risk might be reduced by the inclusion of a provision similar to that in German law, whereby an inventory might be agreed by the parties on entering the marriage, listing the assets already owned by each; where there was no such inventory, it would be presumed that all property was acquired subsequent to the marriage. This would offer protection to spouses

argument against imposing fixed property rights, as it might cause dissension and discourage people from marrying. However, it is respectfully submitted that a couple with fundamentally opposing views on property ownership would perhaps be better not to marry at all, or at least should not enter marriage blindly, as is too often the case.

213 This would be akin to the solution proposed by the LRAC for Northern Ireland (discussed earlier).

214 See Fahey and Lyons, supra n 142, p 121. Similarly, Ward comments that while maintenance may have some relevance for middle and higher income couples, it has little or none for people at the lowest economic level; see Ward, Divorce in Ireland: Who Should Bear the Cost? (1993), p 9: hereinafter Ward (1993).

215 Interestingly, Prager considers that this argument ignores the many other sources of wealth that are increasingly available to modern families (supra n 31, at 7, footnote 21).

216 Supra n 212, para 61(d).

217 See Shatter, supra n 113, p 834.

218 Ibid p 835. 
who entered marriage with a large amount of property, if those spouses wished to avail of the proviso. Where spouses did not prepare an inventory, the property to be divided would be the same as under the current law.

Further, it is not unreasonable to exclude assets acquired prior to the marriage from the community of property, as the impact of this would be felt mostly in marriages of relatively short duration. Where a marriage has endured a number of years, it is likely that a large proportion of property would be acquired after the marriage; similarly, it is probable that a gain would be made. It also seems more just to restrict the division to wealth gained by the joint efforts of the couple, rather than property independently acquired and owned by either. If the division is based on the concept of the family as a partnership, where both spouses contribute to the relationship, it is not unjust to limit the rights acquired by each to the assets or gain jointly made.

The most worrying issue relates to children, as an equal division of assets might preclude the retention of the family home by the primary carer, thus depriving the children of their home. The great advantage of the present discretionary system is that the court has flexibility to cater for the housing needs of the family, which would not be the case in a standard community regime. There is no easy solution to this difficulty. However, it might be worthwhile exploring the possibility of giving courts the power to defer the sale of the family home in the interests of the children ${ }^{219}$ - though this obviously raises other difficulties, both theoretical and practical. ${ }^{220}$

Another key difference would relate to the finality of the arrangement: current legislative policy appears to be heavily set against a "clean break", and therefore, the adoption of a community regime might be regarded as inappropriate. This issue is problematic: as Ward notes, the "clean break" policy applied in the United States has resulted in the impoverishment of many women. ${ }^{221}$ It appears that this difficulty is caused primarily by restrictive maintenance awards, ${ }^{222}$ and it is not clear whether Ward is speaking of community or equitable distribution states. Similar difficulties have arisen in New Zealand, owing to the clean break policy which applies there to both maintenance and asset division. ${ }^{223}$ It is submitted here that a division of family assets under a community regime might go far to alleviate the lot of many former wives, and that where a family has few assets, the "clean break" issue is in fact irrelevant, as far as property distribution is concerned, as there is little or nothing to be divided. Even if there is a "clean break" with regard to property redistribution, there is no reason why maintenance should not be ongoing, particularly where there are children.224 If a marriage is legally terminated, former spouses should not be subjected to

219 This approach is occasionally utilised by the courts under existing law.

220 Alternatively, a custodial spouse might be permitted to buy out the other spouse's interest in the home, though this would not always be possible, for financial reasons.

221 See Ward (1993), supra n 214, p 26.

222 Ibid.

223 See $Z$ v $Z$ (No. 2) [1997] 2 NZLR 258 at $275 \mathrm{ff}$.

224 See the analysis of rationales for maintenance payments in Power, supra $\mathrm{n} 138$, at 17. 
continued readjustment of their property interests, however reasonable maintenance payments may be in many situations.

Assuming the case for a community property regime to be accepted, which form of community should be adopted? It is argued here that the most appropriate system is that of deferred community, which permits maximum freedom with regard to property management during the marriage. A further advantage of a deferred community on the German model is that there is no concept of loss-sharing; effectively what is offered is a regime with many of the advantages of separation of property, but with a certain and predefined division, which treats both spouses equally. Against this must be weighed the advantage to a dependent spouse of feeling that he or she is not deprived of financial power, which is given by a community on the French model (where both spouses have equal management powers), or by the LRAC's proposals in Northern Ireland. O'Connor, for example, argues in favour of a regime offering a present, rather than a deferred interest in family property. ${ }^{225}$ However, it is submitted that the French approach is too restrictive, and too likely to cause administrative difficulties, as well as difficulties for third parties such as creditors. ${ }^{226}$ This may also be a problem in relation to the Northern Ireland proposals, ${ }^{227}$ and the LRAC's recommendations, as discussed earlier, also seem likely to lead to undesirable inequality between older and younger wives.

A specific difficulty raised in the Irish context in the divorce referenda, and subsequently by the Second Commission for the Status of Women, relates to family farms. ${ }^{228}$ It is argued by some that a farm that has been in the family of a particular spouse for generations, should be treated differently to other family assets. Two points may be made in this regard. First, the current legislation makes no distinction between family farms and other property; nor would it be right that it should, where a spouse has contributed many years of work to improving the farm and the fortunes of the family. Second, in a deferred community, what is divided is the increase in value of the assets of the parties, i.e. the "gain" made by each in the course of the marriage. Unlike a community fund on the French model, a financial payment is required, rather than the division of specific assets. If the farm were owned by one of the spouses prior to the marriage, therefore, only half of the increase in value would be payable.

\section{CONCLUSION}

It is submitted that the current Irish approach to matrimonial property shares many of the ideals and aims of community property theory. In particular, the sharing of assets between the spouses in both approaches mirrors an economic and social sharing. However, Irish law falls far short of the

225 O'Connor argues, inter alia, that “. . . rights to property ought not to be postponed until the occurrence of such pathological events as death and marital breakdown." See O'Connor, Key Issues in Irish Family Law (1988), p 214.

226 See, e.g., MacDonald's comments on the drawbacks of the French community property regime: MacDonald, "The French Law of Marriage and Matrimonial Regimes" (1952) 1 ICLQ 313.

227 See Fox, supra n 111.

228 Supra n 196. 
certainty and equality to be desired in this most important area. While this certainty is especially needful in the event of the breakdown of the relationship, it is also highly desirable during the marriage.

The present law offers neither certainty nor finality. It also fails to secure equality for the homemaking spouse, as domestic contributions are consistently undervalued. Although the equitable redistribution approach offers flexibility, it is submitted that the price of this alleged responsiveness, in terms of anxiety, strain and litigation, is too high. A community regime is limited as regards flexibility, but it offers a measure of security, certainty and transparency which, it is contended, is likely to increase both justice and emotional well-being during and after marriage. Consequently, it is argued that the legal position should be altered, and that a regime of deferred community should be constituted the regime of default. Such a change would also promote true equality within marriage.

Whether the community regime should apply to all, or simply to future marriages, would be a matter for debate. In the light of the Supreme Court decision regarding the Matrimonial Homes Bill 1993, it might be thought that the regime should apply to future marriages only. However, given the effect that the current legislative provisions may have on existing property arrangements, it is contended that this argument is illogical. Limiting the application of a community property regime to future marriages only would result in a two-tier system, whereby older spouses in "traditional" marriages, who tend to be the most vulnerable financially, would be afforded least protection. Although there would clearly be considerable difficulties in imposing a new property regime on married couples, ${ }^{229}$ such a change has already effectively been imposed by the 1989, 1995 and 1996 Acts. Perhaps the solution would be to give all couples an equal right to opt out of the community regime, irrespective of the date of marriage. In this situation, the current equitable redistribution principles would continue to apply, with all the uncertainty and risk that they entail. Although such a course might, as the Supreme Court suggested ${ }^{230}$ (and as the LRAC has suggested in the Northern Ireland context) increase marital discord in the short term, in the long term, it is argued that this disadvantage would be outweighed by the benefits of clear and predetermined spousal rights.

229 Even so, a referendum might still be necessary to ensure constitutional compliance. Of particular interest here is the recent Supreme Court decision in Re Art 26 and the Planning and Development Bill 1999 [2000] IESC 20, where the court upheld the compulsory acquisition of privately owned residential development land for social housing. The court was influenced primarily by the social need for low-cost housing, by the fact that only up to $20 \%$ of land could be acquired, and by the fact that compensation was payable to the landowner (albeit at less than market rates). The key question is whether a measure is necessary for the common good, and is a proportionate means of achieving that good; however, less judicial emphasis might be placed on "private" social good (within families or workplaces) than on "public" measures. The judicial approach to interference with private property rights has generally been highly conservative; see, e.g., $L \mathrm{v}$ $L$ [1992] 2 IR 77 (where the court refused to grant the wife a constitutional right to a share in the family home) and Re Art 26 and the Employment Equality Bill 1996 [1997] 2 IR 321 (where the court refused to allow the financial burden of accommodating disabled workers to be placed on employers).

230 Re Matrimonial Homes Bill 1993 [1994] ILRM 241. 